\title{
A review of conflict and cohesion in social relationships in family firms
}

\begin{abstract}
The literature on conflict and cohesion in social relationships in family firms has developed rapidly in recent decades. To take stock and provide directions to move this flourishing research area forward, we conduct a systematic review of the literature. We examine the prevailing conceptualizations of conflict and cohesion in social relationships in family firms, depict their drivers and outcomes, highlight their theoretical and empirical underpinnings, and propose an ontological framework to synthesize this large body of research. Drawing on our review, we identify some important research gaps and suggest fruitful directions for future research.
\end{abstract}

\section{Keywords}

Conflict, Cohesion, Family Business, Literature Review, Ontological Approach

\section{Introduction}

Research on conflict and cohesion in social relationships (CCSR) in family firms (FFs) has burgeoned in the last decades. Conflict and cohesion are two contrasting yet co-existing phenomena that animate any form of business organization (Forbes \& Milliken, 1999), especially FFs (e.g., Björnberg \& Nicholson, 2007). While a significant portion of studies address these issues from a purely economic and/or legal perspective, such as agency conflicts (e.g., Schulze et al., 2003), others are rooted in the behavioral sciences, examining conflict and cohesion as a complex web of social relationships ${ }^{1}$ (e.g., Caputo et al., 2019; Fichman \& Levinthal, 1991; Westphal \& Zajac, 2013). In the context of FFs, this perspective is particularly relevant, since the family dimension typically goes well beyond mere economic and legal aspects, and the complexity of social relationships is especially visible and plays a crucial role in shaping family and firm behavior (Steier et al., 2009).

\footnotetext{
${ }^{1}$ In this study, we refer to conflict as "perceived incompatibilities or discrepant views among the parties involved" (Jehn \& Bendersky, 2003, p. 189) and cohesion as "the tendency of people to stick together" (Carron, 1982).
} 
Therefore, we provide a review of studies dealing with conflict and cohesion in social relationships, i.e., social interactions between individuals or groups of individuals (Westphal \& Zajac, 2013) in the specific context of FFs.

Some scholars see conflict as the source of all evil (a main cause of FF failure) (e.g., Jayantilal et al., 2016) and cohesion as the source of all good (a main cause of FF success) (e.g., FernándezRoca et al., 2014). We argue that these assumptions are too simplistic and misleading, and are one of the main reasons why the literature on this topic remains largely undertheorized and fragmented, resulting in theoretical limitations and empirical indeterminacy. Indeed, understanding the role of CCSR requires a more in-depth examination, since the concepts of cohesion and conflict are more nuanced than often assumed, and can have both positive and negative effects (Ensley et al., 2002). In addition, different types of CCSR may occur simultaneously and are strongly interrelated in FFs (e.g., Kellermanns \& Eddleston, 2004).

Thus, we base our review on two main arguments. First, cohesion is not always good, as it may lead to negative effects such as groupthink and inertia (e.g., Zattoni et al., 2015). Likewise, conflict is not always negative, as it may lead to constructive challenges and improvements (e.g., Ensley \& Pearson, 2005). Second, conflict and cohesion are not necessarily orthogonal, as the absence of conflict does not automatically imply the presence of cohesion, and vice versa. Indeed, in some circumstances, the parties may simultaneously manifest high levels of cohesion and conflict, such as when interactions are very tight and frequent. In other circumstances, groups may simultaneously manifest low levels of conflict and cohesion simply because interactions are quite loose and rare. In addition, prior FF literature reviews mainly focus on intra-family conflicts (Kubíček \& Machek, 2020), conflict management (Caputo et al., 2018; Qiu \& Freel, 2020), the negative effects of conflict, offering practitioner-focused recommendations (Alderson, 2015), whereas to date no reviews have been conducted on cohesion individually or on conflict and cohesion jointly. Given that conflict and cohesion in social relationships typically coexist and can be complementary, 
reviews that overlook one or the other may prevent scholars from identifying promising directions for future research accounting for FF idiosyncrasies and heterogeneous behaviors (shaped by their varying resources and goals) during CCSR episodes (Chrisman et al., 2012; Chua et al., 2012).

In this paper, we review 89 studies on CCSR and make three main contributions. First, we illustrate the CCSR conceptualizations, drivers and outcomes, and how these are interlinked according to the literature. In so doing, we clarify what we know about when and under what circumstances conflict and cohesion can be good or bad in the FF context, highlighting the multifaceted nature of both phenomena. We show that studies focusing on conflict are mainly grounded in socio-psychological theories typical of organizational behavior scholarship, while those focusing on cohesion rely more on family science and family business theories. These two approaches lead to different ways of examining CCSR with conflict typically defined according to type (i.e., relationship, cognitive, and process conflicts) and cohesion according to locus (i.e., whether it occurs within the family, the board/TMT, the organization, etc.), and different explanations of why conflict and cohesion can be both beneficial and detrimental. Overall, such differences make comparison difficult.

As a second contribution, we categorize the conflict and cohesion phenomena according to loci, integrating the conceptualizations in the two different yet interconnected literature streams (Torraco, 2016) to better understand the respective drivers and outcomes, and formulate a more coherent ontological framework based on the loci. This is instrumental for our third contribution: constructing a fruitful research agenda on conflict and cohesion in family firms (Post et al., 2020) that encourages family business scholars to consider the holistic interdependence of conflict and cohesion in FFs rather than studying each phenomenon in isolation or simply considering them as opposites.

Put differently, by reviewing studies dealing with both conflict and cohesion, we present a more comprehensive and two-sided understanding of the current body of knowledge on CCSR in FFs. In so doing, we identify important knowledge gaps and offer promising directions for future research 
on CCSR in FFs, advancing our understanding of the complex web of social relationships that animate FFs (Westphal \& Zajac, 2013). Thus, exploring the factors and mechanisms underlying the coexistence of conflict and cohesion and their interactions provides a promising path toward developing insightful theoretical and empirical contributions that jointly consider the two phenomena, the conditions leading to their occurrence, and how/when family firm leaders should rely on or prevent them.

\section{Methodology}

\section{Article Selection Method}

In view of the scope of our review and to ensure including the relevant studies, we followed the sixstep method reported in Figure 1. First, we searched the ISI Web of Science and Ebsco (Business Source Premier and Econlit) databases for academic publications up to 31 December 2019, with no initial time limit, using the keyword combinations reported in Figure 1 in the title, abstract, or keywords. Additional details on the queries we adopted are included in Table S1 in the Supplement (Andreini et al., 2020). Second, we confined the search to articles published in journals listed in the 2018 Chartered Association of Business Schools' Academic Journal Guide (Franco-Santos \& Otley, 2018). In a third step, we merged the samples from the two databases and eliminated any duplicates, leading to 721 articles. As explained in detail in Table S2 (in the Supplement), we then analyzed each of the articles in a fourth step where one author read the abstracts, dividing them into three categories: A) articles relevant to the research $\left.\operatorname{scope}^{2}, \mathrm{~B}\right)$ articles whose relevance is unclear, and C) non-relevant articles. Finally, in the fifth step, the other authors double-checked the studies in the $\mathrm{A}$ and $\mathrm{C}$ categories, and this was followed by a thorough reading and discussion of the full text of each article in B to allow the authorship team to decide whether they should be placed in the A or $\mathrm{C}$ category. In the sixth and final step, we added 3 articles that were not present in the extracted

\footnotetext{
${ }^{2}$ In this process, we excluded articles focused only on agency conflicts, identity conflicts, and role conflicts, rather than interpersonal conflicts.
} 
database but were deemed relevant for our literature review. Ultimately, this process led to a final sample of 89 articles.

(Insert Figure 1 about here)

\section{Review Method}

Studies on CCSR in FFs are quite variegated, which motivated us to attempt to understand both their structure and content. To do so, we followed Jones et al. (2011) to enrich our systematic review approach, offer an objective understanding of the structure of the literature (e.g., Tranfield et al., 2003), and conduct a thematic ontological analysis (Braun \& Clarke, 2006) to better appreciate their nature and content (Jones et al., 2011).

Systematic Analysis. Systematic literature reviews allow analyzing each study in-depth in a given database, identifying research gaps, and outlining future theoretical and/or methodological research directions (Tranfield et al., 2003). The approach is both systematic and transparent (Denyer \& Tranfield, 2009) to ensure consistent results. Following Jones et al. (2011), we adopted the analytic protocol reported in the Table S2 Supplement, and after the systematic analysis, proceeded with a thematic ontological analysis as described next.

Thematic ontological analysis. We thematically explored the ontology of our sampled articles. More specifically, we organized an ontological classification by identifying for each article the main definitions of conflict and cohesion. We then extensively analyzed each article to inductively identify thematic areas that could describe the various definitions of CCSR through the iterative analytic protocol explained in Table S2. This process led to creating an ontological framework classifying our themes and aggregating them based on similarity. The ontological framework (Figure $2 \mathrm{a}$ and Figure $2 \mathrm{~b}$ ) is reported and explained in detail in the next section.

\section{Findings}


In this section, we first describe our sample articles and the main theoretical lenses adopted in prior CCSR research. Then, we present our full review of this literature distinguishing between studies on conflict, studies on cohesion, and those jointly examining conflict and cohesion. Finally, we bridge the examinations of prior conflict and cohesion research and offer a synoptic view of the field.

As mentioned, prior research has categorized conflict studies by type, whereas cohesion studies are categorized by locus. In particular, the most common definitions of conflict are based on the following types: relationship, succession, cognitive, and process. Relationship conflict is generally defined as "an awareness of interpersonal incompatibilities [that] includes affective components such as feeling tension and friction" (Jehn \& Mannix, 2001, p. 238; Rousseau et al., 2018), succession conflict refers to conflict occurring in relation to succession dynamics (Nicholson, 2008, p.111), cognitive conflict refers to "disagreements about the content of the tasks being performed, including differences in viewpoints, ideas and opinions" (Jehn, 1995, p. 258), while process conflict refers to disagreements on how the work should be performed and how the members of the organization should be involved (Jehn, 1997).

The most common definitions of cohesion are instead based on locus (i.e., where cohesion occurs): family, generations, board/TMT, and organization. Thus, family cohesion refers to cohesion within the family, generational cohesion to cohesion within and between specific generations, board/TMT to cohesion within the board and/or TMT, and organizational cohesion broadly extending to organizational members.

\section{Description of the Sample Articles}

In Table S3 (in the Supplement) we present the list of all the papers included in the review and their main characteristics in terms of method, analyzed sample, theory or perspective adopted, and their focus on conflict and/or cohesion (Fitz-Koch et al., 2018). Based on the analysis, our review shows that of the 89 articles, 47 use quantitative methods, 13 are conceptual, 1 is editorial, 2 are 
commentaries, and 22 adopt qualitative methods. Of these 22 qualitative studies, 4 investigate a single case, while the others use a multiple case study approach, or interviews and observations. Finally, 3 articles in our final sample are reviews that examine the literature on organizational behavior dynamics in FFs (Gagné et al., 2014), the psychological aspects of FF succession (Filser et al., 2013), and evolutionary psychology (Nicholson, 2008), while only 1 study adopts a mixedmethods approach (Björnberg \& Nicholson, 2012). Thus, our review highlights the relative absence of studies on CCSR in FFs adopting qualitative methods, since more than half use quantitative methods.

Most of the quantitative studies (40 out of 47) use cross-sectional data, whereas only 7 employ a longitudinal approach, highlighting a lack of studies adopting this approach, which instead would help scholars and managers gain knowledge on how CCSR dynamics evolve in the FF context. The sample size in the quantitative empirical studies ranges from 34 (Beehr et al., 1997) to 1060 (Chrisman et al., 2012).

As shown in Table S3, the organizations studied in the articles operate in a wide range of industries, with the exception of a limited number of studies focusing on specific sectors: manufacturing (6), automobile (2), wine (2), car dealership (1), sports (1), higher education (1), fashion (1), high-tech (1), and wine and spirits combined (1). Of the 89 articles, 19 are comparative studies of FFs versus non-FFs, while 70 examine FFs only. However, an additional relatively high number of the latter articles (29 out of 70) compare FFs versus non-FFs from a conceptual standpoint.

FFs are ubiquitous and have a significant impact worldwide. This is confirmed by the many nationalities of the firms in the studies. The most analyzed geographic area is Europe (30 articles). Another highly studied area is North America with 24 studies. 7 studies were conducted in Asia, 2 in Africa, 2 in Latin America, and 1 in Oceania. Thus, our review shows that CCSR dynamics are globally recognized as relevant in studying FFs. At the same time, important regions where research 
on CCSR is underrepresented in the literature include Latin America, Africa, South-Eastern Asia, and Eastern Europe, despite their relevance to understanding FF phenomena related to individual and group social interactions resulting from dissimilar cultural dynamics (De Massis et al., 2018).

A relevant portion of the articles in our database (48\%) focus on conflict only, while $29 \%$ focus on cohesion only. $23 \%$ focuses simultaneously on conflict and cohesion. Taken together, our review of the methodological and empirical issues reveals that CCSR dynamics are rarely studied in combination, possibly due to the underlying and widespread assumption that these are two faces of the same coin, and the absence of conflict implies the presence of cohesion, and vice versa.

\section{Theoretical Grounding}

With the analysis of each paper, we also mapped the theoretical perspectives used, and when no explicit reference was made to a theory, we considered the main body of literature the paper was built on (see Table S3 Supplement).

Our review reveals that papers focused on conflict tend to emphasize the use of sociopsychological theories typical of organizational behavior studies. In this regard, three main theoretical approaches are used regardless of the locus of conflict. These are conflict theory (e.g., Cater et al., 2016; Davis \& Harveston, 2001; Kellermanns \& Eddleston, 2004, 2007), stewardship theory (e.g., Eddleston \& Kellermanns, 2007; Discua Cruz et al., 2013), and evolutionary psychology (Nicholson, 2008; Collin \& Ahlberg, 2012). Instead, for some loci, other theories have been specifically adopted. For example, studies dealing with family conflict tend to draw more on identity theory (Le Breton-Miller \& Miller, 2014), social identity theory (Le Breton-Miller \& Miller, 2014; Schmidts, 2013), and theory of relationships (Gagné et al., 2014). Papers focused on generational conflict draw on theories such as the systems psychodynamic perspective (Petriglieri \& Stein, 2012), and leadership theory (Marshall et al., 2006). TMT conflict studies rely on behavioral theories of management teams (Schjoedt et al., 2013) or on a process-based view of boards (Zattoni et al., 2015; Zona, 2014, 2016). Finally, organizational conflict studies instead have taken a broader 
view, including systems theory (Claßen \& Schulte, 2017), multilevel theory (Eddleston et al., 2008), and procedural justice theory (Van der Heyden et al., 2005).

We found that papers focusing on cohesion are mostly grounded in sociological perspectives typical of family science and family business studies. Notably, while family social capital (Carr et al., 2011; Herrero \& Hughes, 2019; Jiménez et al., 2015; Salvato \& Melin, 2008; Sanchez-Ruiz et al., 2019) has been widely used regardless of the locus of cohesion, other sociological theories have been more specifically used for some loci. For example, family cohesion studies use family systems theory (Björnberg \& Nicholson, 2007), attachment theory (Björnberg \& Nicholson, 2012), the family functionality view (Filser et al., 2018), while papers on TMT cohesion introduced social network theory (Athanassiou et al., 2002). In addition to these patterns, as shown in Table S3, there has been a tendency, especially in studies on both conflict and cohesion, to integrate more theories and literature streams.

Thus, while scholars focusing on conflict tend to rely more on theories typical of the organizational behavior field, those focused on cohesion emphasize the use of theories originating from family science and family business studies, and those jointly dealing with conflict and cohesion adopt a mixed approach.

Finally, emerging from our review is that the abovementioned theories used to explain conflict are mainly based on the assumption that whether conflict is beneficial or detrimental depends on the type of conflict analyzed (e.g., cognitive conflict is beneficial, relationship conflict is detrimental, etc.). Instead, theories used to explain cohesion are mainly based on the assumption that whether cohesion is beneficial or detrimental depends on the amount of cohesion observed, thus supporting the "too much of a good thing" effect (Pierce \& Aguinis, 2013). Unfortunately, studies observing both conflict and cohesion simultaneously have not integrated or at least explicitly situated these two assumptions. 
In the following, we examine our sampled papers emphasizing the drivers and outcomes associated with conflict and cohesion in the empirical studies. We start with an analysis of the studies on conflict, followed by those on cohesion, and finally, the studies that jointly examine conflict and cohesion. Worth noting is that, based on the vocabulary the authors use, conflict tends to be conceptualized according to type of conflict (relationship conflict, cognitive conflict, etc.), while cohesion tends to be conceptualized according to locus, i.e., where it occurs (family, board/TMT, etc.). In this review, we reconcile these two approaches, providing a categorization of both conflict and cohesion based on their loci. This has the advantage of: 1) allowing consistent comparisons of studies on conflict and cohesion; 2) being guided by the understanding of loci, a crucial element for any academic study exploring social relationships (Fuhse, 2018).

\section{Studies on Conflict}

\section{Family Conflict}

Conceptualizations. Family conflict refers to all conflicts emerging within the family in general, involves various family members (siblings, spouses, children, or other relatives) regardless of the generation to which they belong (Sonflield \& Lussier, 2009). With few exceptions, family conflict is typically assumed to correspond to relationship conflict, i.e., deriving from interpersonal incompatibilities and including "affective components such as feeling tension and friction" (Jehn \& Mannix, 2001, p. 238; Rousseau et al., 2018).

Drivers and outcomes from empirical research. The empirical literature on family conflicts has privileged the focus on the outcomes rather than drivers. Regarding the latter, a specific FF variable that drives conflict is altruism: when altruism is high, family conflict decreases (Eddleston \& Kellermanns, 2007). Instead, the presence of non-family managers increases family conflict (Sonfield \& Lussier, 2009).

Regarding the outcomes, Eddleston and Kellermanns (2007) in their empirical study find that family conflict negatively influences FF performance, while Chirico and Salvato (2016) find that 
family conflict reduces knowledge internalization and product development. Thus, family conflicts are found to have mainly negative effects. Nevertheless, some different evidence has recently been provided in Rousseau et al. (2018) who find a U-shaped association between family conflict (specifically relationship conflict within the family) and subjective firm valuation.

Worth noting is that all the empirical papers on family conflict have assumed it corresponds to relationship conflict (i.e., related to incompatibilities between family members). As relationship conflict generally leads to negative emotions and perceptions of interpersonal resentment, aversion, and hostility (Jayantilal et al., 2016; Morgan \& Gómez-Mejía, 2014), such assumption has lead scholars studying family conflict to mainly emphasize its negative effects.

\section{Generational Conflict}

Conceptualizations. Generational conflict refers to conflict between two generations, i.e., parentoffspring conflict (e.g., Haberman \& Danes, 2007), and/or conflict within a specific generation (Jayantilal et al., 2016; Nazer \& Llorca-Jaña, 2020). The authors often refer to this as succession conflict since it typically occurs when one generation hands over the business to the next, i.e., succession (Filser et al., 2013; Nicholson, 2008, p.111). It implies disagreements on the transfer of ownership, distribution of management power, or other forms of recognition (e.g., cash) (Marshall et al., 2006). Important to highlight is that generational conflict is expected, at least theoretically, to increase with the number of generations (de Vries, 1993), and is typically intertwined with other forms of conflict.

Drivers and outcomes from empirical research. Contrary to family conflicts, scholars investigating generational conflicts have prioritized understanding the drivers rather than outcomes. Our review of the empirical drivers of generational conflict highlights an emphasis on succession. Planning the succession process can reduce generational conflict (Brenes et al., 2006). Moreover, a strong focus on the family (rather than on the founder) decreases the destructive nature of generational conflict (Kammerlander et al., 2015). Similarly, rivalry and conflict management 
(Pardo-del-Val, 2009), as well as strategies aimed at transmitting responsible family ownership (Aragón-Amonarri et al., 2019) are two important elements reducing succession conflict. On the other hand, the empirical literature has found the following variables increasing succession conflict: the generational shadow of the founder, the presence of a third or later generation leading the FF (Davis \& Harveston, 1999), and projective identification (Petriglieri \& Stein, 2012). The presence of influential family members who are not involved in day-to-day operations has a twofold effect depending on the generation in charge (with the first generation increasing conflict and the third or later generation decreasing it). Instead, the presence of influential family members who are active in day-to-day operations increases generational conflict (Davis \& Harveston, 2001). Finally, Cater et al. (2016) highlight that different approaches to successor team formation lead to increasing or decreasing family conflict.

With regard to the few studies examining the outcomes of generational conflict, it has been found that it can prevent smooth FF transition (Morris et al., 1997), reduce innovation (Kammerlander et al., 2015), and ultimately reduce firm continuity (Kiong, 2005). Finally, while generational conflict undermines FF longevity, it can potentially be positive, as it leads to the creation of new ventures by successors (Cater et al., 2016).

Thus, prior research on generational conflict has highlighted its many causes (mostly derived from factors that are distinctive to FFs), assuming it to be strictly related to succession and mainly detrimental.

\section{Board/TMT Conflict}

Conceptualizations. Board/TMT conflict refers to disagreement or argument within groups such as TMTs and boards (Bettinelli, 2011; Forbes \& Milliken, 1999; Zattoni et al., 2015). Probably as a consequence of the application of a process-based view of boards, all scholars studying conflicts in boards and TMTs have focused on cognitive conflict, i.e., "disagreements about the content of the 
tasks being performed, including differences in viewpoints, ideas and opinions" (Jehn, 1995, p. 258).

\section{Drivers and outcomes from empirical research.}

With respect to the drivers, Zona (2014) finds an inverted U-shaped relationship between the level of board ownership dispersion among family directors and board/TMT (cognitive) conflict, that is, board/TMT cognitive conflict is high when there is a moderate number of owners on the board with equal ownership dispersion, while it is low with excessively high or low levels of ownership dispersion. Instead, Zattoni et al. (2015) find that family involvement in the business (i.e., family members with voting control and active in the firm) reduces board/TMT cognitive conflict.

Zona (2016) finds that in the presence of a family CEO leading the FF, there is greater board/TMT (cognitive) conflict, resulting in positive outcomes for the firm compared to when a non-family CEO leads the FF (Zona, 2016). This finding demonstrates that families can create an atmosphere where cognitive conflict produces a benefit for the firm ${ }^{3}$. Moreover, the presence of cognitive conflict is found to positively affect board strategy tasks and (indirectly) firm performance (Zattoni et al., 2015), monitoring activities, and firm value (Goergen et al., 2015).

In sum, our review of the empirical studies reveals that board/TMT cognitive conflict is portrayed as beneficial, as it can increase decision-making quality and improve understanding thanks to the questioning it implies and the increased range of options it offers decision-makers (Zattoni et al., 2015).

\section{Organizational Conflict}

Conceptualizations. Organizational conflict refers to disagreements or arguments at the organizational level within the FF, mainly observed among FF employees. Perhaps due to covering

\footnotetext{
${ }^{3}$ We thank an anonymous reviewer for this comment.
} 
a wide variety of circumstances, studies examining organizational conflict have taken into account different types, including relationship, cognitive, and process conflict, i.e., disagreements on how the work should be performed and how the members of the organization should be involved (Jehn, 1997).

Drivers and outcomes from empirical research. Considering the drivers of organizational (process) conflict, Van der Heyden et al. (2005) show that the introduction of fair decision-making processes reduces organizational conflict in FFs. Moreover, empirical research on organizational (relationship) conflict shows that when decision-making is highly participative, ownership concentration in one or two generations leads to a decrease in organizational conflict, whereas it increases when ownership is concentrated in multiple (more than two) generations (Eddleston et al., 2008).

Regarding the outcomes of organizational conflict, Kellermanns and Eddleston (2007) find that organizational (process) conflict positively affects performance when there is high perception of family-member exchange. Conversely, organizational (process) conflict leads to lower performance when such perception is low (Kellermanns \& Eddleston, 2007). Regarding the outcomes of organizational (cognitive) conflict, prior research has confirmed that while organizational (cognitive) conflict is overall seen positively, its effects are not always positive as different contingencies may intervene. In this vein, Kellermanns and Eddleston (2007) find a negative relationship between organizational (cognitive) conflict and firm performance moderated by familymember exchange and generational ownership dispersion.

Taken together, the insights from empirical studies on organizational conflict support the idea that the effects of organizational process and cognitive conflict on performance can be twofold (Kellermanns \& Eddleston, 2004), depending on some intervening family variables (contingencies).

\section{Studies on Cohesion}




\section{Family Cohesion}

Conceptualizations. We include in this category the studies where cohesion occurs within the family locus, referring to how family members feel bonded with each other (Olson \& Gorall, 2003). Family cohesion is generally defined as “an individual's sense of belonging to a particular family and his or her feelings of morale associated with membership in the family" (Bollen \& Hoyle, 1990, p. 482). It typically involves "the strength of the emotional bond perceived by the family members" (Cabrera-Suárez et al., 2014, p. 290), i.e., the glue that holds family members together.

Undoubtedly, the family cohesion concept is closely related to that of family harmony. Family harmony, despite the different name, is generally conceptualized and measured in ways that echo family cohesion (e.g., Scholes et al., 2016; Venter et al., 2003) ${ }^{4}$.

Family cohesion (or family harmony) is theoretically presented in prior research as beneficial, particularly because it facilitates the pursuit of collective organizational goals (e.g., Sanchez-Ruiz et al., 2019). On the other hand, theoretical insights emerge on the fact that excessive cohesiveness leads to avoiding dissent, limiting the possibility of considering different decisional options (Zahra, 2012), and eventually a lack of sufficient openness to diverse external perspectives (Beavers \& Voeller, 1983; Björnberg \& Nicholson, 2012).

Drivers and outcomes from empirical research. With respect to the drivers of family cohesion, Konopaski et al. (2015) reveal that shared experience and co-participation among family members increase family cohesion. In the same vein, family functionality is found to intensify family cohesion (Filser et al., 2018). In a quantitative study of US FFs, Chrisman et al. (2012) find that the percentage of ownership held by the family and the number of family generations involved increase family

\footnotetext{
4 A different case is "organizational harmony" that instead refers to the quality of work relationships within an organization and cannot be considered synonymous of family cohesion.
} 
harmony ${ }^{5}$. Family social capital ${ }^{6}$ is another driver that facilitates/improves family cohesion (Salvato \& Melin, 2008). Family cohesion is also found to moderate the relationship between family ownership and organizational learning. More specifically, the positive influence of family ownership on organizational learning (i.e., learning breadth and learning speed) is greater when family cohesion is high (Zahra, 2012).

Regarding the outcomes, family cohesion is found to lead to higher family identification with the firm (Cabrera-Suárez et al., 2014), innovativeness of the family (Filser et al., 2018), level of perceived emotional ownership (Björnberg \& Nicholson, 2012), and level of risk-taking over time (Vollero et al., 2019). FF's ability to access and recombine external resources and generate family members' human capital is another positive outcome. Indeed, high levels of family cohesion facilitate access to and the creation and transformation of useful resources for the FF, even in difficult circumstances (Salvato \& Melin, 2008). Finally, family cohesion (again in terms of family harmony $^{7}$ ) also exerts significant effects during the succession process. High levels of harmony among family members and between the owner-manager and the successor increase the successor's satisfaction with the succession process (Venter et al., 2003). Thus, despite that excessive family cohesion is theorized as potentially detrimental, empirical data so far has focused only on its beneficial effect.

\section{Generational Cohesion}

Conceptualizations. We include in this thematic area studies dealing with the various forms of bonds/ties among members of different generations (inter-generational cohesion) and/or within the

\footnotetext{
${ }^{5}$ In this study, family harmony (a synonym of cohesion) is seen as a central sub-dimension of the importance of familycentered non-economic goals.

${ }^{6}$ Worth noting is that our ontological analysis indicates that family social capital (FSC) and family cohesion are two separate concepts: while the former refers to resources stemming from social relationships, i.e., the structural, relational, and cognitive dimensions of bonding ties within the family (Herrero, 2018; Arregle et al., 2007), the latter refers to the family members' predisposition to stick together, and therefore pertains to the strength of such ties more as an outcome/consequence of FSC resources/features (Pearson et al., 2014; Carron, 1982). Thus, FSC has enough distinguishing characteristics for it not to be an unnecessary redundancy/neologism.

${ }^{7}$ Here harmony is measured with items that evoke cohesion, for example, during the succession process, family members "cared about each other's welfare" and "appreciated each other" (p. 13).
} 
same generation (intra-generational cohesion). The concept of generational cohesion seems particularly promising in that it sheds light on the possible dynamics beyond inter-and intragenerational relationships that have often been studied in the case of generational conflict but not cohesion. For example, in their conceptual work, Waldkirch et al. (2018) develop propositions on generational cohesion that could be tested empirically in future research by focusing on the extent of affective attachment between two different generations of the owning family and a non-family CEO.

Drivers and outcomes from empirical research. As mentioned, no empirical studies focus on generational cohesion. Instead, some empirical evidence has been produced in the studies that jointly examine conflict and cohesion, an aspect to which we will return later.

\section{Board/TMT Cohesion}

Conceptualizations. We include in this thematic area articles dealing with the bonds/ties that exist among TMTs and board members. Board/TMT cohesion differs from family cohesion, as the latter refers to bonding/closeness within the family system while the former refers to bonding/closeness within management or governance groups, such as the TMT and the board (Ensley et al., 2007). Of course, the distinctive features of FFs' TMT and board cohesion refer to kinship ties among TMTs and board members that go well beyond business relationships, and at least theoretically, may be both positive and negative for the FF, in as much as they could lead to groupthink (Bettinelli, 2011).

Drivers and outcomes from empirical research. Among the studies considering cohesion, Bettinelli (2011) identifies outside directors' presence as an important driver of board cohesion. In particular, the higher the number of outside directors, the greater the board's cohesion. Finally, Kaczmarek et al. (2012) find that cohesion, proxied by the presence of board faultlines, increases firm performance. Founder centrality is found to positively influence TMT cohesion ${ }^{8}$ (Athanassiou

\footnotetext{
${ }^{8}$ Here TMT cohesion is seen as a synonym of top management team and founder congruence (see Athanassiou et al., 2002, p. 142).
} 
et al., 2002), in turn positively affecting the achievement of family-oriented objectives and social performance. In sum, not many empirical studies consider board/TMT cohesion and those that do it emphasize its benefits despite that also in this case, at least theoretically, it is argued that excessive board cohesion may be detrimental (Forbes \& Milliken, 1999).

\section{Organizational Cohesion}

Conceptualizations. The distinctive connotation of this theme is that it refers to bonds/ties within the organization. In this context, the articles in our sample conceptualize organizational cohesion as an organizational capability (Carr et al., 2011) or the firms' commitment to develop a cohesive internal community (Miller et al., 2009). A common approach used in studies on organizational cohesion is relying on the feedback of non-family employees using Beehr's (1996) scale to measure their perception of the extent of cohesion with co-workers (Jiménez et al., 2015; Vallejo, 2009; Vallejo-Martos, 2011).

Drivers and outcomes from empirical research. Regarding the drivers, Jiménez et al. (2015) ${ }^{9}$ show that trust and work climate have a positive effect on group cohesion among family and nonfamily FF members. The FF is more likely to be cohesive when it has a better work climate and higher trust among its members. In the same vein, transformational leadership, commitment, and organizational harmony are three drivers that positively influence organizational cohesion ${ }^{10}$ (organizational harmony and cohesion among the organization's members are conceptually distinct) (Vallejo, 2009; Vallejo-Martos, 2011). Finally, Carr et al. (2011) show that another positive driver of group cohesion is the FF's internal social capital. Interestingly, our review reveals that the studies examining organizational cohesion consider only the drivers, overlooking the outcomes.

\section{Studies Jointly Examining Conflict and Cohesion}

\footnotetext{
${ }^{9}$ The authors see trust, participation, and work climate as elements of organizational harmony, while cohesion is seen as an aspect of firm performance (p. 269).

${ }^{10}$ Specifically, organizational harmony is observed through working environment/atmosphere, participation, and trust (p. 456), while "cohesion among organization members" is identified as an aspect of firm performance (p. 468).
} 
The articles that examine both conflict and cohesion in the same study tend to simultaneously explore different types of conflict and different types of cohesion. Considering the empirical literature, a first group of papers focuses on the relationship between conflict and cohesion. Van der Merwe et al. (2012) find that variables such as fairness, mutual trust, commitment, openness, and peace (defined as lack of conflict) are drivers that favor harmonious family relations ${ }^{11}$ (seemingly conceptualized as family cohesion). Therefore, trust emerges as a driver of cohesion that increases when conflict is lacking. A different perspective is proposed in a more recent inductive investigation finding that family cohesion leads to trust, which in turn reduces cognitive and process conflict (Kudlats et al., 2019). Therefore, trust is acknowledged as both a driver and an outcome of cohesion. In the study of Van der Merwe et al. (2012), lack of conflict is argued to determine an increase in family cohesion, whereas in Kudlats et al. (2019), increased cohesion is found to indirectly decrease conflict. Kidwell et al. (2012) find that family cohesion ${ }^{12}$ reduces relationship conflict. Simultaneously, relationship conflict mediates the negative relation between family cohesion and perceptions of family member impediment. Overall, these articles seem to detect a vicious circle between conflict and cohesion. In addition, they exemplify the conception of conflict and cohesion as orthogonal/opposite, leading to the "either/or" dichotomy. This view, we argue, can be misleading, because it is virtually impossible to determine what causes what.

Therefore, understanding CCSR as two possible coexisting phenomena might be more fruitful. In this regard, Scholes et al. (2016) offer more counterintuitive results showing the dark side of cohesion and conflict, finding that family cohesion (conceptualized as family harmony) ${ }^{13}$ limits the internationalization process in small FFs in that high levels of family harmony negatively affect external networks and the resources deployed to internationalization, while relationship conflict

\footnotetext{
11 "Harmonious family relationships refer to relationships among family members characterized by support, appreciation, care, emotional attachment and cooperation." (p. 19)

12 Here, family cohesion is seen as "perceived family harmony norms."

${ }^{13}$ The authors refer to family harmony as the creation of "orderly, stable, and socially integrating structures that bind the family together" (p. 138).
} 
reduces human and financial capital. Relationship conflict is found to prevent FF growth, while pruning the family tree enhances family cohesion (Lambrecht \& Lievens, 2008).

Other studies instead offer more articulated views of the conflict-cohesion relationship and their respective drivers and outcomes. Considering succession conflict and family cohesion, Jaskiewicz et al. (2016) find that family cohesion (defined as family unity), a cohesive family culture, and egalitarian leadership style are negative drivers of generational conflict, and positive drivers of intergenerational transfer. Indeed, intergenerational conflict tends to be present when family continuity is prioritized over family unity (cohesion among family members), while conflict is reduced when the FF has a cohesive family culture and egalitarian leadership style. According to Jaskiewicz et al. (2016), FFs following an "interwoven approach" (i.e., where both the family logic - family continuity and family unity - and the commercial logic are considered important and influence firm behavior) are more likely to succeed over generations due to the cohesive family culture and egalitarian leadership style preventing conflict during succession. These features help FFs implement strict family rules and a long-term intergenerational perspective.

Nazer and Llorca-Jaña (2020) show that the success of firm transition is an outcome of both generational conflict and family cohesion, albeit with opposite relationships. Successful intergenerational transfer is more likely in FFs with cohesive family structures and harmony ${ }^{14}$ among successors. Conversely, hostile family rivalries reduce the likelihood of succession (Nazer \& Llorca-Jaña, 2020) and can lead to the breakup of a group business assets (Fernández-Roca et al., 2014). Highly cohesive family structures facilitate FFs in overcoming critical financial periods (Nazer \& Llorca-Jaña, 2020). Moreover, FF longevity is a positive outcome of generational cohesion (Fernández-Roca et al., 2014; Nazer \& Llorca-Jaña, 2020), while respecting the founder's premises increases generational cohesion (Fernández-Roca et al., 2014).

\footnotetext{
${ }^{14}$ Family harmony is here viewed in terms of family cohesion, "family harmony amongst successors (i.e., strong emotional capital present in the family firm)" (p. 19).
} 
Focusing on the father-offspring management transfer, Haberman and Danes (2007) find that the feeling of exclusion is a positive driver of generational conflict but a negative driver of generational cohesion. Indeed, the authors show that when daughters feel excluded from FFs, higher levels of conflict manifest, and family-firm cohesion decreases. This leads to the allocation of limited resources to non-collective goals, lower trust, and fewer coalitions within the FF decision team (Haberman \& Danes, 2007). Thus, the articles presented above on cohesion and conflict (FernándezRoca et al., 2014; Haberman \& Danes, 2007; Jaskiewicz et al., 2016; Nazer \& Llorca-Jaña, 2020) tend to present the view that cohesion is the source of all good, and conflict is the source of all evil.

Instead, Ensley et al.'s (2007) article is a good example of how jointly studying conflict and cohesion can reveal the coexisting and not necessarily contrasting/orthogonal positions of conflict. i.e., conflict is not always bad. Ensley et al. (2007) show that in FFs, both short- and long-term pay dispersions generate harmful conflict. On the one hand, both types of pay dispersions positively affect relationship conflict. On the other hand, they negatively influence cohesion among the TMT. Moreover, short-term pay dispersion negatively influences cognitive conflict. The authors show that these effects on conflict and cohesion are stronger in FFs than in non-FFs. In addition, TMT conflict and cohesion dynamics are drivers of firm performance. More specifically, cognitive conflict and TMT cohesion positively affect FF performance, while relationship conflict negatively affects firm performance.

Comparing different TMT compositions, Ensley and Pearson (2005) find that parental TMTs and non-family TMTs both lead to better team dynamics than TMTs composed of siblings or cousins without parental ties (familial TMTs). Interestingly, TMTs composed of members with parental ties outperform non-family TMTs. Even if parental TMTs have a lower level of positive cognitive conflict, they have a higher level of cohesion, shared strategic cognition, and reduced relationship conflict than non-family TMTs and familial TMTs. In addition, non-family TMTs show less relationship conflict, higher cohesion, and higher shared cognition than TMTs composed of siblings 
or cousins. This study again shows that different types of CCSR can coexist and lead to different results.

\section{Bridging the Examinations of Conflict and Cohesion: A Synopsis}

Based on the state-of-the-art of the literature on CCSR presented above, in this section we summarize our findings and offer an ontological framework that organizes the literature on CCSR in FFs.

A major challenge of the analyzed literature is that authors focusing on conflict have used categories based on type (i.e., focusing on the "what" of conflict: relationship, succession, cognitive, and process), while authors focusing on cohesion have used categories based on loci (i.e., focusing on the "context" of cohesion: family, generational, board/TMT, and organizational), and those focusing on both conflict and cohesion have adopted a mix of these two strategies. In addition, our review shows that these two approaches have led to not only using different vocabularies but also different theories and assumptions on whether conflict is always detrimental and cohesion is always beneficial. Our effort to review the studies on conflict and those on cohesion based on their loci is reported in Tables A1 and A2 (in the Appendix) where we categorize conflict and cohesion studies by locus, the drivers and outcomes of conflict and cohesion, and outline the theories used in each paper. These tables are particularly useful to quickly grasp the main concepts, categories, and theories used to study conflict and cohesion (both separately and jointly) in family firms. Moreover, they offer a basis to build an ontological framework.

(Insert Figures $2 \mathrm{a}$ and $2 \mathrm{~b}$ about here)

Thus, drawing on our analysis summarized in Tables A1 and A2, and in the spirit of synthesizing the findings from our review and connecting the examinations of conflict and cohesion in prior research, we have created an ontological framework mapping the literature on CCSR in FFs (Figure 2a and Figure 2b) following Jones et al. (2011). This framework illustrates both conflict and 
cohesion as homogeneously coded by locus, thereby allowing comparisons and intersections between the two streams. More specifically, the framework shows the different conceptualizations of conflict (Figure 2a) and cohesion (Figure 2b) that emerged from our thematic classification, illustrating for each of these conceptualizations the respective drivers and outcomes found in empirical and conceptual works (with an asterisk). The bolded citations are the minority of works that focus on conflict and cohesion in the same study, whereas in the box above this framework we have summarized the main theoretical perspectives adopted, distinguishing between those used in conflict studies from those used in cohesion studies. As such, this framework offers a useful means to identify important research gaps (e.g., the boxes displaying a lower number of studies) and future research directions. We will elaborate on this in the next section.

In sum, our literature review reveals that conflict and cohesion in social relationships are multifaceted constructs with both positive and negative implications, consistent with prior research portraying most dynamics animating FFs as Janus-faced (Miller et al., 2015).

There is large consensus that these two important phenomena explain a number of dynamics that involve the family, the organization, and its components. There are several contributions that examine conflict in its negative aspects and cohesion in its positive aspects. In contrast, less emphasis is placed on analyzing conflict and cohesion jointly, however the studies that do so assume that an increase in the former leads to a decrease in the latter, and vice versa. Developing a better understanding of this link would significantly advance research and management practice.

\section{Future Research Agenda}

Our review of studies on CCSR in FFs has highlighted that both phenomena are multifaceted and nuanced, and thus require in-depth studies, avoiding oversimplifications or implicit assumptions on their positive or negative nature and their reciprocal relationships. In this section, we examine the 
main research gaps with the aim of identifying some promising directions for future research as summarized in Table 1.

(Insert Table 1 about here)

\section{Opportunities for Future Research that Examines the Bright Side of Conflict}

Our review reveals that conflict is largely examined in its negative aspects, overlooking the potential positive aspects of conflict. In studies focused on conflict and those that jointly analyze conflict and cohesion, conflict is examined principally for its negative impact on FFs and their behavior and outcomes. This may in part be due to the fact that studies on conflict in social relationships in FFs mainly focus on specific forms of conflict. More precisely, most of the analyzed studies investigate generational conflict and relationship conflict within the family, given the relevance and specificity of interpersonal ties and relationships in FFs. These forms of conflict typically involve negative emotions and jeopardize FF management, especially in relation to some situational events such as succession.

Conversely, process conflict is rarely studied in the context of FFs (particularly at the family and board/TMT level). Thus, we see the need for future research to investigate the occurrence of this form of conflict in FFs, and its potential negative and especially positive implications. Indeed, process conflict has been identified as potentially beneficial for organizations, since it may favor the evaluation of different options and contribute to the involvement of different actors (Morgan \& Gómez-Mejía, 2014). Understanding whether, how, and at which level (family, generational, board/TMT, organization) process conflict can help FFs improve their processes and their internal organization is a promising direction for future research.

Moreover, our review reveals that in the context of FFs, prior research has studied cognitive conflict by frequently focusing on its occurrence in the board and TMT. This choice is justified by the central role these groups play in decision-making processes. However, it would be interesting to investigate the presence of cognitive conflict that also involves individuals who are not part of 
the board/TMT but are salient FF stakeholders, for example, major shareholders or those playing a relevant role in the family system. Family members with different links to the firm and/or different roles in the organization may, for instance, have contrasting perspectives on the optimal balance between the family logic and the commercial logic (Chrisman et al., 2012; Kotlar \& De Massis, 2013), and depending on their goals and goal systems, may lead to a positive or negative effect (Chua et al., 2018). Thus, it seems interesting to investigate cognitive conflict at the family level and try to understand more in detail the role that this kind of conflict can play in explaining family conflict.

Another related aspect deserving attention in future research is the study of conditions that may lead to a beneficial or detrimental effect of cognitive conflict in FFs. On the one hand, in FFs, individuals often have strong links, common backgrounds and shared values, potentially leading to engaging in groupthink. As such, they may take advantage of cognitive conflict that may lead them to consider different perspectives and evaluate the pros and cons of various options. On the other hand, conflict may have an emotional cost (Jayantilal et al., 2016), which increases with affective commitment, and may thus be particularly relevant in the presence of family ties. Understanding the circumstances under which cognitive conflict may positively or negatively shape FF behavior is an area ripe for future research.

Furthermore, as process conflict may also imply disagreement on the tasks that different family members perform (Kellermanns \& Eddleston, 2004), it might cause or be influenced by relationship conflict and generational conflict. At the same time, high levels of cognitive conflict in FFs may lead to relationship conflict (Kellermanns \& Eddleston, 2007). Thus, a better understanding of the reciprocal relationships between different forms of conflict could help identify under what conditions and to what extent process conflict could be beneficial or detrimental for FF behavior.

Similarly, it would be interesting to investigate whether and under what conditions a certain (moderate) level of relationship conflict has a positive effect by favoring beneficial forms of 
conflict, such as cognitive conflict. As emerged from our review, prior studies suggest that relationship conflict largely has a negative nature, since it generally leads to negative emotions and affective components (Jehn \& Mannix, 2001, p. 238; Rousseau et al., 2018). At the same time, other studies highlight that in FFs, the desire to preserve family harmony and avoid personal conflicts might lead them to avert potentially beneficial forms of conflict (Zattoni et al., 2015). Thus, future research might investigate whether moderate levels of relationship conflict help reduce the avoidance of confrontation and explicit manifestation of disagreement, favoring a beneficial cognitive conflict. It might also investigate whether and under what conditions this positive effect compensates the traditional negative effects of relationship conflict.

More generally, we see the need for future studies aimed at better understanding how one form of conflict influences the others, and how different forms of conflict interact. This would be helpful to develop an integrative framework that not only takes into account all the forms of conflict identified in this review, but also their interconnections and possible implications in terms of conflict management. In this perspective, the ontological framework we have developed may support future research by highlighting the various levels at which the analysis of conflict may be conducted. Focusing the analysis on each specific locus (family, generational, board/TMT, organization) and at the same time taking into account different types of conflict may help in investigating the interrelationships between different forms of conflict to better understand whether and how a specific locus favors some type of conflict, unearthing the negative or positive dimension of conflict.

Future research might also adopt multi-theoretical perspectives or an assemblage approach (DeLanda, 2006a, 2006b; Deleuze \& Guattari, 1987) to investigate the issues associated with the occurrence and nature of conflict at multiple levels of analysis. Interestingly, prior studies mainly rely on the use of socio-psychological theories typical of organizational behavior studies, signaling the need to integrate them with perspectives that contemplate the heterogeneity of the family system 
and its idiosyncrasies. In the assemblage theory perspective, the FF becomes an assemblage of logics and routines that are inevitably destabilized with the manifestation of conflict. Scholars are therefore called on to investigate the processes associated with such destabilization and consequent restabilization.

\section{Opportunities for Future Research that Examines the Dark Side of Cohesion}

Our review shows that the potentially negative aspects associated with cohesion have received little attention, as most of the reviewed studies focus on its positive aspects.

Indeed, prior research has studied cohesion in FFs at different levels (family, generational, board/TMT, organization), focusing in almost all cases on the benefits associated with the presence of cohesion. Nevertheless, there is also evidence of a possible negative implication of high levels of cohesion. For example, Scholes et al. (2016) show that the desire to maintain family harmony, which frequently characterizes FFs (Gómez-Mejía et al., 2007), may constrain their decision-making processes, their willingness to commit financial resources, and consequently, the execution of their strategic decisions, specifically those regarding internationalization. Moreover, very high cohesion - and the desire to maintain it - may favor groupthink and the tendency to align with the opinion of other members of the group (family, TMT, or board) with potentially detrimental effects on group outcomes.

Thus, we see the need for future research to examine the possible negative consequences of high cohesion by investigating its impact on the effectiveness of decision-making processes and on decisions concerning resource allocation and the strategies to pursue, disentangling how cohesion is positively or negatively related to outcomes. It would also be interesting to investigate the distinctive features of FFs to understand whether the risks associated with "excess" cohesion or with extreme importance attributed to cohesion are higher in FFs than in non-FFs, such as due to the emotional involvement of family members. 
Exploring the effect of extremely low levels of cohesion to understand whether this simply implies the absence of the positive outcomes identified in prior studies is another promising research direction. In general, the absence of cohesion differs from the presence of conflict, even if the two phenomena might occur simultaneously. It would thus be interesting to disentangle how the effects of low cohesion differ from those associated with the presence of conflict, and their interconnections.

Again, we see the need for future research to adopt multi-theoretical perspectives or an assemblage approach (DeLanda, 2006a, 2006b; Deleuze \& Guattari, 1987) to investigate the issues associated with the occurrence and nature of cohesion at multiple levels of analysis. Prior studies on cohesion mainly rely on the use of sociological perspectives typical of family science and family business studies, signaling the need to integrate them with perspectives that contemplate the psychological microfoundations of FF behavior (Picone et al., 2021). Assemblage theory allows viewing cohesion as a process of destabilization and consequent re-stabilization of FF logics and routines, and drawing on cognitive and social psychology research - especially psychology studies that explore a wide array of behavioral traits, including individual cognitive processes (Groome, 2013), personality disorders (Tyrer et al., 2015), sensation and perception, attention, motivation, and attachment (Kalat, 2013) - can be particularly promising to further our understanding of cohesion in social relationships in FFs.

\section{Opportunities for Future Research that Jointly Examines Conflict and Cohesion}

A key finding of our review is that most studies focus on either conflict or cohesion, with limited attention to a joint investigation of the two phenomena. Thus, we see the need to further examine conflict and cohesion through research designs that allow theorizing on their simultaneous presence in the FF setting. While several of the studies reviewed mention both conflict and cohesion as relevant elements that can help explain FF dynamics, the number of studies that explicitly investigate and operationalize these two phenomena in an empirical analysis is quite limited. 
Moreover, the few contributions that jointly study conflict and cohesion in most cases investigate their relationships with other variables rather than their interaction, without univocal findings on the relationship between conflict and cohesion, and the possible antecedent-outcome links. Thus, future studies that explicitly consider conflict and cohesion and their reciprocal influence would contribute to our understanding of whether cohesion is helpful to avoid conflict, or conversely, whether the strict relationship and attachment that accompany cohesion generate or exacerbate conflict. For instance, cohesion between family members, the board/TMT, or the FF might create the incentive to prevent conflict and/or adopt constructive confrontation that helps mitigate and manage it. On the other hand, the perception of strong ties and the importance attributed to relationships within the FF in the presence of high cohesion might create conflict or emphasize the emotional cost of conflict and its negative implications. In this regard, previous studies highlight that highly cohesive family members are "locked" into the firm, and this condition may favor the persistence of conflict and increase its costs (Frank et al., 2011; Kellermanns \& Eddleston, 2004). Likewise, we have limited knowledge on whether the emergence of conflict within the family and/or business has an impact on cohesion or on the perception of cohesion of the actors involved. Moving beyond considering conflict and cohesion as opposites would help shed light on these dynamics and the reasons that spur individuals in FFs to alternate between conflict and cohesion. Although outside the scope of our review, prior research on entrepreneurial teams has acknowledged that social relationships are essential to understanding FF behavior (e.g., Schjoedt et al., 2013). We thus encourage future scholars to review the entrepreneurial teams literature to see if and how aspects related to CCSR might have been examined, and identify any potential insight that might contribute to theory building in the FF setting ${ }^{15}$.

The reviewed studies reveal that the positive or negative effect of conflict and cohesion may depend on the intensity of these phenomena, since the level of CCSR may influence how they affect

\footnotetext{
${ }^{15}$ We thank an anonymous reviewer for this comment.
} 
FF behaviors and performance, and there might be optimum levels of CCSR. An interesting direction for future research therefore lies in going beyond the study of linear relationships and exploring the possible presence of curvilinear relationships that link CCSR to FF performance. The study of Rousseau et al. (2018) has already moved in this direction, highlighting a U-shaped relationship between family relationship conflict and subjective firm valuation. Further research is needed to investigate non-linear relationships between different forms of conflict and cohesion, and different dimensions of firm performance. Even the interdependence between conflict and cohesion might be better understood by exploring non-linear relationships. For example, it may be that an increase in cohesion helps reduce conflicts, but after a certain point, an excessive level of cohesion might lead to an increase in conflict and related costs (due to frequent interactions, strict relationships, and emotional involvement). We thus call for studies that investigate U-shaped (or other non-linear) relationships between conflict and cohesion in FFs. In conducting these studies, as Haans et al. (2016) suggests, it would be particularly important to theorize the underlying mechanisms that may explain these relationships. In this perspective, the present review serves as a springboard for future research by showing the multifaceted nature of both conflict and cohesion, and mapping the different outcomes they may determine in FFs.

Finally, the few studies that jointly examine conflict and cohesion focus on some combinations of specific forms of conflict and specific forms of cohesion, while other combinations have not been taken into account. Even so, different forms of conflict can coexist with different forms of cohesion. For instance, FF cohesion might coexist with process conflict and cognitive conflict, or organizational cohesion might coexist with different forms of conflict. Understanding the conditions that determine the coexistence of different forms of conflict and cohesion, and the effects of their joint presence, is certainly a promising area for future research. In this regard, our ontological framework that allows identifying a correspondence between the locus of conflict and cohesion may also be used to guide future research, offering different contexts in which the relationship between 
conflict and cohesion may be studied (family, generations, board/TMT, organization). Focusing on each may allow understanding whether the context (locus) influences how conflict and cohesion interrelate.

In sum, our literature review suggests the need to better understand: (i) whether different forms of conflict and cohesion coexist, given that the conceptualizations of these two phenomena and some empirical evidence suggest that one is not the opposite of the other, and the presence of one does not necessarily correspond with the absence of the other; (ii) the interrelationships and reciprocal influences between conflict and cohesion, and different forms thereof.

\section{Opportunities for Future Research Comparing FFs and Non-FFs}

Our review has highlighted that empirical studies on conflict and/or cohesion in FFs have focused in the majority of cases on FFs alone. This in part is related to the focus on forms of conflict and cohesion that are specific to FFs, such as family conflict, generational conflict, generational cohesion, and family cohesion. In these cases, the object of study implies the need to limit the analysis to FFs.

In other cases, the empirical analyses have been conducted on samples of FFs even if the object of study consists of forms of conflict and cohesion that may be present in any type of business organization. This approach limits the possibility of understanding the distinctive nature of conflict and cohesion in FFs. We thus see the need for research that compares FFs and non-FFs to understand whether the particularities of FFs have an impact on different aspects, such as the importance attributed to organizational and board/TMT cohesion, the capabilities and ways to achieve cohesion, the emotional cost of conflict, the modes and capabilities to manage it. The reviewed literature suggests that the role played by the family in FFs may have an impact on the presence and level of conflict (Ensley \& Pearson, 2005), and that FFs represent a particular context that may influence how some conditions affect conflict and cohesion (Ensley et al., 2007). For example, Jiménez et al. (2015) highlight that FFs are characterized by higher levels of trust, participation, and better work 
climate than their non-family counterparts. At the same time, other studies argue that FFs may have a tendency to avoid conflicts - including those that are potentially beneficial, such as cognitive conflict (Zattoni et al., 2015) - to preserve the family's harmony. This is related to the risk that cognitive conflicts in FFs are misperceived as personal attacks, leading to hostility and personal conflicts. Given that for family members it may be difficult to separate work (in the FF) and family, it is more likely that disagreements about work related issues may become personal and imply animosity (Kellermanns \& Eddleston, 2007). Examining and applying theories gleaned from family science (e.g., Jaskiewicz et al., 2017) may provide a multidisciplinary approach to understand the role of the family system in distinctively shaping conflicts and cohesion in FFs compared to nonFFs.

\section{Opportunities for Future Research that Examines Family Firm Heterogeneity}

Even if empirical studies have mainly focused on FFs, relatively limited attention has been devoted to the drivers of heterogeneity that may determine variations in the occurrence of conflict and cohesion. Despite this, we know that FFs are heterogeneous (Chua et al., 2012). We thus see the need to further explore what aspects of FF heterogeneity drive differences in conflict and cohesion across FFs. As FF governance is a primary driver of heterogeneity (Daspit et al., 2018), we welcome future research that digs deeper into the role of heterogeneous governance structures in shaping the conflict and/or cohesion dynamics. To give an example, FFs vary not only in composition (e.g., according to different aspects, such as the family vs. non-family nature, gender, generation), but also in the functioning of the board (Arzubiaga et al., 2018), and this may engender different conflict and/or cohesion dynamics. Likewise, different FFs are endowed with different family governance structures (e.g., family councils, family trustees), which may again determine variations in types of conflict and cohesion, and their magnitude. Moreover, FFs vary in terms of the governance practices adopted (Chrisman et al., 2018), and this may again differently shape the conflict and/or cohesion dynamics. For example, some FFs introduce clear and predefined entry requirements for the next 
generation, whereas others do not, which might lead to divergences in the occurrence of conflict (Brenes et al., 2006).

Two other important drivers of FF heterogeneity are goals and resources (Chrisman et al., 2013). Goal-related sources of heterogeneity include the strength of FF vision (Barnett et al., 2012), and the dimension of socioemotional wealth that the controlling family emphasizes (Cennamo et al., 2012; Chua et al., 2015). Resource-related heterogeneity stems from family-based human assets (Verbeke \& Kano, 2012), path dependence in resource accumulation (Arregle et al., 2012), tacit knowledge that accumulates through long tenure (Kotlar et al., 2020), and social capital that can be useful for resource exploration and exploitation (Muñoz-Bullón et al., 2020; Zellweger et al., 2019). Building on these sources of heterogeneity, future scholars might explore how divergent goals and resource configurations differently shape CCSR in FFs.

Finally, governance, goals, and resources can vary across FFs controlled by different generations (Fang et al., 2018; Gersick et al., 1997), and might depend on temporal factors, such as the duration of family involvement or the occurrence of intra-family succession (Kotlar et al., 2020). Thus, we see the need to explore how variations in these aspects among FFs may determine heterogeneity in the probability of the occurrence, nature, and levels of conflict and cohesion. Again, drawing more on family science theories may help in theorizing how and why conflict and cohesion differ across family firms depending on different family structures, functions, interactions, and events (Jaskiewicz \& Dyer, 2017).

\section{Method and Data Challenges}

The proposed directions for future research imply method and data challenges, as pursuing our proposed research agenda requires different approaches to those that mainly characterize extant research on this topic. 
Prior studies are largely cross-sectional and do not allow understanding how conflict and cohesion change over time, or testing causation. Thus, we encourage scholars to conduct longitudinal studies that embrace a dynamic perspective of conflict and cohesion, as this would advance knowledge on the processes that characterize the temporal evolution of conflict and cohesion, and allow more rigorous theorizing of the reciprocal influences of conflict and cohesion. For example, future research might try to investigate how single or repeated episodes of conflict affect the attitude towards potential future conflicts (making them more likely or favoring their avoidance). Similarly, it would be interesting to investigate how high levels of cohesion and/or a high importance attributed to cohesion affect the capability to manage subsequent episodes of conflict, and how these conflicts affect the level of cohesion. Future research might also seek to understand whether family conflicts tend to be at the origin of board/TMT and organizational conflicts, or conversely, board/TMT and organizational conflicts lead to conflict within the family.

Moreover, among the empirical studies reviewed, quantitative studies prevail over qualitative studies, even if qualitative research can be particularly useful to deepen understanding of the processes and complex interrelations of CCSR in FFs (De Massis \& Kammerlander, 2020), and the contextual influences that might affect whether and how cohesion and conflict occur. Future research could therefore adopt qualitative approaches to unveil the event histories, the actionformation mechanisms, and why and how the processes and dynamics related to conflict and cohesion unfold. For instance, multiple case studies would allow comparing the different conflict/cohesion processes, and building theory on the causal links that explain the outcome variations. Ethnographic approaches and process studies would allow understanding the emergence, transformation, and adaptation of conflict and/or cohesion over time. Discourse studies instead would enable analyzing the narratives that determine the actions, meaning, and interactions of those involved in the conflict and/or cohesion dynamics (e.g., analyzing oral or written communication patterns). Given the relevance of accounting for the perceptions of different actors involved in the 
conflict and/or cohesion phenomena, qualitative studies could be designed for a multi-level analysis, and a view of these phenomena based on different perspectives (differently from most quantitative analyses based on single-respondent questionnaires).

Mixed-method research designs would also be fruitful to complement and contextualize the insights gathered from qualitative studies, or develop propositions for subsequent quantitative testing. In addition, experimental methods (in the field, lab, or online) would enable analyzing the micro-dynamics of conflict and/or cohesion formation, management, and dissolution, including isolating the causal mechanisms. Experimental approaches may also be especially useful to investigate top-down (treatment) effects, such as exploring the affective and psychological microfoundations of conflict and cohesion behavior (De Massis \& Foss, 2018). Finally, simulations (e.g., agent-based models) of the emergent outcomes of simultaneously interacting rule-based micro agents (i.e., different family or non-family members) might allow accounting for a particular observed conflict or cohesion outcome, such as control and access to resources. As such, simulations are particularly useful to investigate the bottom-up emergence of conflict and cohesion, modeling aggregation as it unfolds over time. Other methods, such as qualitative comparative analysis (QCA), might be helpful to identify and compare different configurations of FF characteristics, and how changes in configurations result in similar conflict and/or cohesion outcomes.

Finally, our review reveals that prior CCSR studies have been mainly conducted in Europe and North America, while other geographic areas, such as Latin America, Eastern Europe, and Africa, have been largely overlooked. Institutional factors, such as national culture, may affect not only the approaches FFs adopt to manage conflict and cohesion, but also the roles of different family actors (e.g., female vs. male, new vs. old generation) in the conflict and/or cohesion dynamics, and the strength of family ties among them. Likewise, the values of the family involved in the business, as well as its structure and functions, might vary across different institutional settings. Thus, we see 
the need for future research in these overlooked areas, ideally cross-country studies that detect potential institutional effects on the conflict and cohesion dynamics in FFs.

In sum, to advance the FF CCSR literature, future research might expand not only the research methods but also the types of data used.

\section{Conclusion}

We have systematically reviewed the literature on CCSR in FFs and built the connections between conflict and cohesion investigations through an ontological classification of prior research. Based on our ontological framework and the insights from our literature review, we provide a focused set of suggestions for future research. Research on conflict and cohesion in FFs has advanced considerably over the past decades, and we hope that our efforts to review and organize knowledge on this topic will lead to furthering our understanding of conflict, cohesion, and related phenomena. However, there remain many opportunities for family business and entrepreneurship researchers to engage more fully with conflict, cohesion, and their relationship in FFs from a theoretical, empirical, and methodological standpoint. 
References (The asterisk indicates studies examining CCSR in FFs)

Alderson, K. (2015). Conflict management and resolution in family-owned businesses: A practitioner focused review. Journal of Family Business Management, 5(2), 140-156.

*Anderson, R. C., \& Reeb, D. M. (2004). Board composition: Balancing family influence in S\&P 500 firms. Administrative Science Quarterly, 49(2), 209-237.

Andreini, D., Bettinelli, C., Pedeliento, G., \& Apa, R. (2020). How do consumers see firms' family nature? A review of the literature. Family Business Review, 33(1), 18-37.

*Aragón-Amonarriz, C., Arredondo, A. M., \& Iturrioz-Landart, C. (2019). How can responsible family ownership be sustained across generations? A family social capital approach. Journal of Business Ethics, 159(1), 161-185.

Arregle, J. L., Hitt, M. A., Sirmon, D. G., \& Very, P. (2007). The development of organizational social capital: Attributes of family firms. Journal of Management Studies, 44(1), 73-95.

Arregle, J. L., Naldi, L., Nordqvist, M., \& Hitt, M. A. (2012). Internationalization of familycontrolled firms: A study of the effects of external involvement in governance. Entrepreneurship Theory and Practice, 36(6), 1115-1143.

Arzubiaga, U., Kotlar, J., De Massis, A., Maseda, A., \& Iturralde, T. (2018). Entrepreneurial orientation and innovation in family SMEs: Unveiling the (actual) impact of the board of directors. Journal of Business Venturing, 33(4), 455-469.

*Athanassiou, N., Crittenden, W. F., Kelly, L. M., \& Marquez, P. (2002). Founder centrality effects on the Mexican family firm's top management group: Firm culture, strategic vision and goals, and firm performance. Journal of World Business, 37(2), 139-150.

*Avloniti, A., Iatridou, A., Kaloupsis, I., \& Vozikis, G. S. (2014). Sibling rivalry: Implications for the family business succession process. International Entrepreneurship and Management Journal, 10(4), 661-678.

Barnett, T., Long, R. G., \& Marler, L. E. (2012). Vision and exchange in intra-family succession: Effects on procedural justice climate among nonfamily managers. Entrepreneurship Theory and Practice, 36(6), 1207-1225.

Beavers, W. R., \& Voeller, M. (1983). Family models: Comparing and contrasting the Olson circumplex model with the Beavers systems model. Family Process, 22(1), 85-98.

Beehr, T. A. (1976). Perceived situational moderators of the relationship between subjective role ambiguity and role strain. Journal of Applied Psychology, 61(7), 35-40.

*Beehr, T. A., Drexler Jr, J. A., \& Faulkner, S. (1997). Working in small family businesses: empirical comparisons to non-family businesses. Journal of Organizational Behavior, 18(3), 297-312.

Berrone, P., Cruz, C., \& Gómez-Mejía, L. R. (2012). Socioemotional wealth in family firms: Theoretical dimensions, assessment approaches, and agenda for future research. Family Business Review, 25(3), 258-279.

*Bettinelli, C. (2011). Boards of directors in family firms: An exploratory study of structure and group process. Family Business Review, 24(2), 151-169.

*Björnberg, Å., \& Nicholson, N. (2007). The family climate scales: Development of a new measure for use in family business research. Family Business Review, 20(3), 229-246.

*Björnberg, A., \& Nicholson, N. (2012). Emotional ownership: The next generation's relationship with the family firm. Family Business Review, 25(4), 374-390.

*Bobillo, A. M., Rodríguez-Sanz, J. A., \& Tejerina-Gaite, F. (2013). Shareholder activism and internationalization in the family firm. Journal of Business Economics and Management, 14(5), $867-885$.

Bollen, K. A., \& Hoyle, R. H. (1990). Perceived cohesion: A conceptual and empirical examination. Social Forces, 69(2), 479-504.

Braun, V., \& Clarke, V. (2006). Using thematic analysis in psychology. Qualitative Research in Psychology, 3(2), 77-101. 
*Brenes, E. R., Madrigal, K., \& Molina-Navarro, G. E. (2006). Family business structure and succession: Critical topics in Latin American experience. Journal of Business Research, 59(3), 372-374.

*Cabrera-Suárez, M. K., Déniz-Déniz, M. D. L. C., \& Martín-Santana, J. D. (2014). The setting of non-financial goals in the family firm: The influence of family climate and identification. Journal of Family Business Strategy, 5(3), 289-299.

Caputo, A., Marzi, G., Maley, J., \& Silic, M. (2019). Ten years of conflict management research 2007-2017: An update on themes, concepts and relationships. International Journal of Conflict Management, 30(1), 87-110.

Caputo, A., Marzi, G., Pellegrini, M. M., \& Rialti, R. (2018). Conflict management in family businesses: A bibliometric analysis and systematic literature review. International Journal of Conflict Management, 29(4), 519-542.

*Carr, J. C., Cole, M. S., Ring, J. K., \& Blettner, D. P. (2011). A measure of variations in internal social capital among family firms. Entrepreneurship Theory and Practice, 35(6), 1207-1227.

Carron, A. V. (1982). Cohesiveness in sport groups: Interpretations and considerations. Journal of Sport Psychology, 4(2), 123-138.

*Cater III, J. J., Kidwell, R. E., \& Camp, K. M. (2016). Successor team dynamics in family firms. Family Business Review, 29(3), 301-326.

*Chirico, F., \& Salvato, C. (2016). Knowledge internalization and product development in family firms: When relational and affective factors matter. Entrepreneurship Theory and Practice, 40(1), 201-229.

*Chirico, F., Sirmon, D. G., Sciascia, S., \& Mazzola, P. (2011). Resource orchestration in family firms: Investigating how entrepreneurial orientation, generational involvement, and participative strategy affect performance. Strategic Entrepreneurship Journal, 5(4), 307-326.

Chrisman, J. J., Chua J. H., Le Breton-Miller, I., Miller, D., \& Steier L. (2018). Governance mechanisms and family firms. Entrepreneurship Theory and Practice, 42(2), 171-186.

*Chrisman, J. J., Chua, J. H., Pearson, A. W., \& Barnett, T. (2012). Family involvement, family influence, and family-centered non-economic goals in small firms. Entrepreneurship Theory and Practice, 36(2), 267-293.

Chrisman, J. J., Sharma, P., Steier, L. P., \& Chua, J. H. (2013). The influence of family goals, governance, and resources on firm outcomes. Entrepreneurship Theory and Practice, 37(6), 1249-1261.

Chua, J. H., Chrisman, J. J., \& De Massis, A. (2015). A closer look at socioemotional wealth: Its flows, stocks, and prospects for moving forward. Entrepreneurship Theory and Practice, 39(2), 173-182.

Chua, J. H., Chrisman, J. J., De Massis, A., \& Wang, H. (2018). Reflections on family firm goals and the assessment of performance. Journal of Family Business Strategy, 9(2), 107-113.

Chua, J. H., Chrisman, J. J., Steier, L. P., \& Rau, S. B. (2012). Sources of heterogeneity in family firms: An introduction. Entrepreneurship Theory and Practice, 36(6), 1103-1113.

Cennamo, C., Berrone, P., Cruz, C., \& Gómez-Mejía, L. R. (2012). Socioemotional wealth and proactive stakeholder engagement: Why family-controlled firms care more about their stakeholders. Entrepreneurship Theory and Practice, 36(6), 1153-1173.

*Claßen, C. A. E., \& Schulte, R. (2017). How do conflicts impact change in family businesses? The family system and familiness as a catalytic converter of change. Journal of Organizational Change Management, 30(7), 1198-1212.

*Collin, S. O. Y., \& Ahlberg, J. (2012). Blood in the boardroom: Family relationships influencing the functions of the board. Journal of Family Business Strategy, 3(4), 207-219.

Daspit, J. J., Chrisman, J. J., Sharma, P., Pearson, A. W., \& Mahto, R. V. (2018). Governance as a source of family firm heterogeneity. Journal of Business Research, 84, 293-300. 
*Davis, P. S., \& Harveston, P. D. (1999). In the founder's shadow: Conflict in the family firm. Family Business Review, 12(4), 311-323.

*Davis, P. S., \& Harveston, P. D. (2001). The phenomenon of substantive conflict in the family firm: A cross-generational study. Journal of Small Business Management, 39(1), 14-30.

*De Clercq, D., \& Belausteguigoitia, I. (2015). Intergenerational strategy involvement and family firms' innovation pursuits: The critical roles of conflict management and social capital. Journal of Family Business Strategy, 6(3), 178-189.

DeLanda, M. (2006a). A new philosophy of society. London: Continuum International Publishing Group.

DeLanda, M. (2006b). Deleuzian social ontology and assemblage theory. In M. Fuglsang \& B. Meier Sorensen (Eds.), Deleuze and the social (pp. 250-266). Edinburgh, UK: Edinburgh University Press.

Deleuze, G. \& Guattari, F. (1987). A thousand plateaus. Minneapolis: University of Minnesota Press.

De Massis, A., \& Foss, N. J. (2018). Advancing family business research: The promise of microfoundations. Family Business Review, 31(4), 386-396.

De Massis, A., Frattini, F., Majocchi, A., \& Piscitello, L. (2018). Family firms in the global economy: Toward a deeper understanding of internationalization determinants, processes, and outcomes. Global Strategy Journal, 8(1), 3-21.

De Massis, A., \& Kammerlander, N. (Eds.). (2020). Handbook of qualitative research methods for family business. Edward Elgar Publishing, Cheltenham Glos, UK.

Denyer, D., \& Tranfield, D. (2009). Producing a systematic review. In D. A. Buchanan \& A. Bryman (Eds.), The Sage handbook of organizational research methods (pp. 671-689). Sage Publications Ltd.

*de Vries, M. F. K. (1993). The dynamics of family controlled firms: The good and the bad news. Organizational Dynamics, 21(3), 59-71.

*Discua Cruz, A., Howorth, C., \& Hamilton, E. (2013). Intrafamily entrepreneurship: The formation and membership of family entrepreneurial teams. Entrepreneurship Theory and Practice, 37(1), $17-46$.

*Duréndez, A., Madrid-Guijarro, A., \& Hernández-Cánovas, G. (2019). Do family firms' specific governance mechanisms moderate the cost of debt? Australian Accounting Review, 29(1), 4963.

*Eddleston, K. A., \& Kellermanns, F. W. (2007). Destructive and productive family relationships: A stewardship theory perspective. Journal of Business Venturing, 22(4), 545-565.

*Eddleston, K. A., \& Morgan, R. M. (2014). Trust, commitment and relationships in family business: Challenging conventional wisdom. Journal of Family Business Strategy, 5(3), 213216.

*Eddleston, K. A., Otondo, R. F., \& Kellermanns, F. W. (2008). Conflict, participative decisionmaking, and generational ownership dispersion: A multilevel analysis. Journal of Small Business Management, 46(3), 456-484.

*Ensley, M. (2006). Family businesses can out-compete: As long as they are willing to question the chosen path. Entrepreneurship Theory and Practice, 30(6), 747-754.

*Ensley, M. D., \& Pearson, A. W. (2005). An exploratory comparison of the behavioral dynamics of top management teams in family and nonfamily new ventures: Cohesion, conflict, potency, and consensus. Entrepreneurship Theory and Practice, 29(3), 267-284.

Ensley, M. D., Pearson, A. W., \& Amason, A. C. (2002). Understanding the dynamics of new venture top management teams: cohesion, conflict, and new venture performance. Journal of Business Venturing, 17(4), 365-386. 
*Ensley, M. D., Pearson, A. W., \& Sardeshmukh, S. R. (2007). The negative consequences of pay dispersion in family and non-family top management teams: An exploratory analysis of new venture, high-growth firms. Journal of Business Research, 60(10), 1039-1047.

Fang, H., Kotlar, J., Memili, E., Chrisman, J. J., \& De Massis, A. (2018). The pursuit of international opportunities in family firms: Generational differences and the role of knowledge-based resources. Global Strategy Journal, 8(1), 136-157.

*Fernández-Roca, F. J., López-Manjón, J. D., \& Gutiérrez-Hidalgo, F. (2014). Family cohesion as a longevity factor of business with intergenerational transmission. Enterprise \& Society, 15(4), 791-819.

Fichman, M., \& Levinthal, D. A. (1991). Honeymoons and the liability of adolescence: A new perspective on duration dependence in social and organizational relationships. Academy of Management Review, 16(2), 442-468.

*Filser, M., De Massis, A., Gast, J., Kraus, S., \& Niemand, T. (2018). Tracing the roots of innovativeness in family SMEs: The effect of family functionality and socioemotional wealth. Journal of Product Innovation Management, 35(4), 609-628.

*Filser, M., Kraus, S., \& Märk, S. (2013). Psychological aspects of succession in family business management. Management Research Review, 36(3), 256-277.

Fitz-Koch, S., Nordqvist, M., Carter, S., \& Hunter, E. (2018). Entrepreneurship in the agricultural sector: A literature review and future research opportunities. Entrepreneurship Theory and Practice, 42(1), 129-166.

Forbes, D. P., \& Milliken, F. J. (1999). Cognition and corporate governance: Understanding boards of directors as strategic decision-making groups. Academy of Management Review, 24(3), 489505.

Franco-Santos, M., \& Otley, D. (2018). Reviewing and theorizing the unintended consequences of performance management systems. International Journal of Management Reviews, 20(3), 696730.

Frank, H., Kessler, A., Nosé, L., \& Suchy, D. (2011). Conflicts in family firms: State of the art and perspectives for future research. Journal of Family Business Management, 1(2), 130-153.

Fuhse, J. A. (2018). Deconstructing and Reconstructing Social Networks. In F. Depelteau (Ed.), The Palgrave handbook of relational sociology (pp. 457-479). Palgrave Macmillan, Cham.

*Gagné, M., Sharma, P., \& De Massis, A. (2014). The study of organizational behaviour in family business. European Journal of Work and Organizational Psychology, 23(5), 643-656.

Gersick, K. E., Davis, J. A., Hampton, M. M., \& Lansberg, I. (1997). Generation to generation: Life cycles of the family business. Boston, MA: Harvard Business School Press.

*Goergen, M., Limbach, P., \& Scholz, M. (2015). Mind the gap: The age dissimilarity between the chair and the CEO. Journal of Corporate Finance, 35, 136-158.

Gómez-Mejía, L. R., Haynes, K. T., Núñez-Nickel, M., Jacobson, K. J., \& Moyano-Fuentes, J. (2007). Socioemotional wealth and business risks in family-controlled firms: Evidence from Spanish olive oil mills. Administrative Science Quarterly, 52(1), 106-137.

Groome, D. (2013). An introduction to cognitive psychology: Processes and disorders. Psychology Press.

*Haberman, H., \& Danes, S. M. (2007). Father-daughter and father-son family business management transfer comparison: Family FIRO model application. Family Business Review, 20(2), 163-184.

Haans, R. F., Pieters, C., \& He, Z. L. (2016). Thinking about U: Theorizing and testing U-and inverted U-shaped relationships in strategy research. Strategic Management Journal, 37(7), $1177-1195$.

*Herrero, I. (2018). How familial is family social capital? Analyzing bonding social capital in family and nonfamily firms. Family Business Review, 31(4), 441-459. 
*Herrero, I., \& Hughes, M. (2019). When family social capital is too much of a good thing. Journal of Family Business Strategy, 10(3), 100271.

Jaskiewicz, P., Combs, J., Shanine, K., \& Kacmar, M. (2017). Introducing the family: A review of family science with implications for management research. Academy of Management Annals, 11(1), 309-341.

Jaskiewicz, P., \& Dyer, W. G. (2017). Addressing the elephant in the room: Disentangling family heterogeneity to advance family business research. Family Business Review, 30, 111-118.

*Jaskiewicz, P., Heinrichs, K., Rau, S. B., \& Reay, T. (2016). To be or not to be: How family firms manage family and commercial logics in succession. Entrepreneurship Theory and Practice, 40(4), 781-813.

*Jayantilal, S., Jorge, S. F., \& Palacios, T. M. B. (2016). Effects of sibling competition on family firm succession: A game theory approach. Journal of Family Business Strategy, 7(4), 260-268.

Jehn, K. A. (1995). A multimethod examination of the benefits and detriments of intragroup conflict. Administrative Science Quarterly, 40(2), 256-282.

Jehn, K. A. (1997). A qualitative analysis of conflict types and dimensions in organizational groups. Administrative Science Quarterly, 42(3), 530-557.

Jehn, K. A., \& Bendersky, C. (2003). Intragroup conflict in organizations: A contingency perspective on the conflict-outcome relationship. Research in Organizational Behavior, 25, 187242.

Jehn, K. A., \& Mannix, E. A. (2001). The dynamic nature of conflict: A longitudinal study of intragroup conflict and group performance. Academy of Management Journal, 44(2), 238-251.

*Jiménez, M. C. R., Martos, M. C. V., \& Jiménez, R. M. (2015). Organisational harmony as a value in family businesses and its influence on performance. Journal of Business Ethics, 126(2), 259272.

Jones, M. V., Coviello, N., \& Tang, Y. K. (2011). International entrepreneurship research (19892009): A domain ontology and thematic analysis. Journal of Business Venturing, 26(6), 632659.

*Kaczmarek, S., Kimino, S., \& Pye, A. (2012). Board task-related faultlines and firm performance: A decade of evidence. Corporate Governance: An International Review, 20(4), 337-351.

Kalat, J. W. (2013). Introduction to psychology. Wadsworth Cengage Learning.

*Kammerlander, N., Dessi, C., Bird, M., Floris, M., \& Murru, A. (2015). The impact of shared stories on family firm innovation: A multicase study. Family Business Review, 28(4), 332-354.

*Kellermanns, F. W., \& Eddleston, K. A. (2004). Feuding families: When conflict does a family firm good. Entrepreneurship Theory and Practice, 28(3), 209-228.

*Kellermanns, F. W., \& Eddleston, K. A. (2007). A family perspective on when conflict benefits family firm performance. Journal of Business Research, 60(10), 1048-1057.

*Kidwell, R. E., Kellermanns, F. W., \& Eddleston, K. A. (2012). Harmony, justice, confusion, and conflict in family firms: Implications for ethical climate and the "fredo effect". Journal of Business Ethics, 106(4), 503-517.

*Kiong, T. C. (2005). Feuds and legacies: Conflict and inheritance in Chinese family businesses. International Sociology, 20(1), 45-70.

*Konopaski, M., Jack, S., \& Hamilton, E. (2015). How family business members learn about continuity. Academy of Management Learning \& Education, 14(3), 347-364.

Kotlar, J., \& De Massis, A. (2013). Goal setting in family firms: Goal diversity, social interactions, and collective commitment to family-centered goals. Entrepreneurship Theory and Practice, 37(6), 1263-1288.

Kotlar, J., De Massis, A., Frattini, F., \& Kammerlander, N. (2020). Motivation gaps and implementation traps: The paradoxical and time-varying effects of family ownership on firm absorptive capacity. Journal of Product Innovation Management, 37(1), 2-25. 
Kubíček, A., \& Machek, O. (2020). Intrafamily conflicts in family businesses: A systematic review of the literature and agenda for future research. Family Business Review, 33(2), 194-227.

*Kudlats, J., McDowell, W. C., \& Mahto, R. V. (2019). Unrelated but together: Trust and intergroup relations in multi-family businesses. Journal of Business Research, 101, 750-756.

*Lambrecht, J., \& Lievens, J. (2008). Pruning the family tree: An unexplored path to family business continuity and family harmony. Family Business Review, 21(4), 295-313.

*Le Breton-Miller, I., \& Miller, D. (2014). Temporal considerations in the study of family firms: Reflections on "the study of organizational behaviour in family business". European Journal of Work and Organizational Psychology, 23(5), 669-673.

*Lee, J. (2006). Impact of family relationships on attitudes of the second generation in family business. Family Business Review, 19(3), 175-191.

* Levinson, H. (1971). Conflicts that plague family businesses. Harvard Business Review, 49(2), 90-98.

*Long, R. G., \& Mathews, K. M. (2011). Ethics in the family firm: Cohesion through reciprocity and exchange. Business Ethics Quarterly, 21(2), 287-308.

*Marshall, J. P., Sorenson, R., Brigham, K., Wieling, E., Reifman, A., \& Wampler, R. S. (2006). The paradox for the family firm CEO: Owner age relationship to succession-related processes and plans. Journal of Business Venturing, 21(3), 348-368.

*Michael-Tsabari, N., \& Tan, W. L. (2013). Exploring family features in non-family organizations: The family metaphor and its behavioral manifestations. Entrepreneurship Research Journal, 3(3), 391-424.

*Michael-Tsabari, N., \& Weiss, D. (2015). Communication traps: Applying game theory to succession in family firms. Family Business Review, 28(1), 26-40.

*Miller, D., Lee, J., Chang, S., \& Le Breton-Miller, I. (2009). Filling the institutional void: The social behavior and performance of family versus non-family technology firms in emerging markets. Journal of International Business Studies, 40(5), 802-817.

Miller, D., Wright, M., Breton-Miller, I. L., \& Scholes, L. (2015). Resources and innovation in family businesses: The Janus-face of socioemotional preferences. California Management Review, 58(1), 20-40.

*Morgan, T. J., \& Gómez-Mejía, L. (2014). Hooked on a feeling: The affective component of socioemotional wealth in family firms. Journal of Family Business Strategy, 5(3), 280-288.

*Morris, M. H., Williams, R. O., Allen, J. A., \& Avila, R. A. (1997). Correlates of success in family business transitions. Journal of Business Venturing, 12(5), 385-401.

Muñoz-Bullón, F., Sanchez-Bueno, M. J., \& De Massis, A. (2020). Combining internal and external R\&D: the effects on innovation performance in family and nonfamily firms. Entrepreneurship Theory and Practice, 44(5), 996-1031.

*Nazer, J. R., \& Llorca-Jaña, M. (2020). Succession in large nineteenth-century Chilean family businesses. Business History, https://doi.org/10.1080/00076791.2020.1717471.

*Nicholson, N. (2008). Evolutionary psychology and family business: A new synthesis for theory, research, and practice. Family Business Review, 21(1), 103-118.

Olson, D. H., \& Gorall, D. M. (2003). Circumplex model of marital and family systems. In F. Walsh (Ed.) Normal family processes: Growing diversity and complexity (3rd ed.) (pp. 514-548). New York: Guilford Press.

*Pardo-del-Val, M. (2009). Succession in family firms from a multistaged perspective. International Entrepreneurship and Management Journal, 5(2), 165-179.

*Pearson, A. W., Bergiel, E., \& Barnett, T. (2014). Expanding the study of organizational behaviour in family business: Adapting team theory to explore family firms. European Journal of Work and Organizational Psychology, 23(5), 657-664.

*Petriglieri, G., \& Stein, M. (2012). The unwanted self: Projective identification in leaders' identity work. Organization Studies, 33(9), 1217-1235. 
Picone P. M., De Massis A., Tang Y., Piccolo R. F. (2021). The psychological foundations of management in family firms: Values, biases, and heuristics. Family Business Review. In press. https://doi.org/10.1177/0894486520985630.

Pierce, J. R., \& Aguinis, H. (2013). The too-much-of-a-good-thing effect in management. Journal of Management, 39(2), 313-338.

Post, C., Sarala, R., Gatrell, C., \& Prescott, J. E. (2020). Advancing theory with review articles. Journal of Management Studies, 57(2), 351-376.

*Qin, Z., \& Deng, X. (2016). Government and family guanxi in Chinese private firms: perceptions and preference. Review of Managerial Science, 10(1), 35-60.

Qiu, H., \& Freel, M. (2020). Managing family-related conflicts in family businesses: A review and research agenda. Family Business Review, 33(1), 90-113.

*Rousseau, M. B., Kellermanns, F., Zellweger, T., \& Beck, T. E. (2018). Relationship conflict, family name congruence, and socioemotional wealth in family firms. Family Business Review, 31(4), 397-416.

*Salvato, C., \& Melin, L. (2008). Creating value across generations in family-controlled businesses: The role of family social capital. Family Business Review, 21(3), 259-276.

*Samara, G., Jamali, D., \& Lapeira, M. (2019). Why and how should SHE make her way into the family business boardroom? Business Horizons, 62(1), 105-115.

*Sanchez-Ruiz, P., Daspit, J. J., Holt, D. T., \& Rutherford, M. W. (2019). Family social capital in the family firm: A taxonomic classification, relationships with outcomes, and directions for advancement. Family Business Review, 32(2), 131-153.

*Schjoedt, L., Monsen, E., Pearson, A., Barnett, T., \& Chrisman, J. J. (2013). New venture and family business teams: Understanding team formation, composition, behaviors, and performance. Entrepreneurship Theory and Practice, 37(1), 1-15.

*Schmidts, T. (2013). Social identity theory and the family business: A contribution to understanding family business dynamics. Small Enterprise Research, 20(2), 76-86.

*Scholes, L., Mustafa, M., \& Chen, S. (2016). Internationalization of small family firms: The influence of family from a socioemotional wealth perspective. Thunderbird International Business Review, 58(2), 131-146.

Schulze, W. S., Lubatkin, M. H., \& Dino, R. N. (2003). Exploring the agency consequences of ownership dispersion among the directors of private family firms. Academy of Management Journal, 46(2), 179-194.

*Sciascia, S., Mazzola, P., \& Chirico, F. (2013). Generational involvement in the top management team of family firms: Exploring nonlinear effects on entrepreneurial orientation. Entrepreneurship Theory and Practice, 37(1), 69-85.

* Sharma, P., \& Sharma, S. (2011). Drivers of proactive environmental strategy in family firms. Business Ethics Quarterly, 21(2), 309-334.

*Sonfield, M. C., \& Lussier, R. N. (2009). Non-family-members in the family business management team: A multinational investigation. International Entrepreneurship and Management Journal, 5(4), 395-415.

*Spriggs, M., Yu, A., Deeds, D., \& Sorenson, R. L. (2013). Too many cooks in the kitchen: Innovative capacity, collaborative network orientation, and performance in small family businesses. Family Business Review, 26(1), 32-50.

*Sreih, J. F., Lussier, R. N., \& Sonfield, M. C. (2019). Differences in management styles, levels of profitability, and performance across generations, and the development of the family business success model. Journal of Organizational Change Management, 32(1), 32-50.

Steier, L. P., Chua, J. H., \& Chrisman, J. J. (2009). Embeddedness perspectives of economic action within family firms. Entrepreneurship Theory and Practice, 33(6), 1157-1167.

Torraco, R. J. (2016). Writing integrative literature reviews: Using the past and present to explore the future. Human Resource Development Review, 15(4), 404-428. 
Tranfield, D., Denyer, D., \& Smart, P. (2003). Towards a methodology for developing evidenceinformed management knowledge by means of systematic review. British Journal of Management, 14(3), 207-222.

Tyrer, P., Reed, G. M., \& Crawford, M. J. (2015). Classification, assessment, prevalence, and effect of personality disorder. The Lancet, 385(9969), 717-726.

*Vallejo, M. C. (2009). Analytical model of leadership in family firms under transformational theoretical approach: An exploratory study. Family Business Review, 22(2), 136-150.

*Vallejo-Martos, M. C. (2011). The organizational culture of family firms as a key factor of competitiveness. Journal of Business Economics and Management, 12(3), 451-481.

*Van der Heyden, L., Blondel, C., \& Carlock, R. S. (2005). Fair process: Striving for justice in family business. Family Business Review, 18(1), 1-21.

*Van der Merwe, S. P., Venter, E., \& Farrington, S. M., (2012). An assessment of selected family business values in small and medium-sized family businesses. South African Journal of Business Management, 43(4), 17-31.

*Venter, E., Boshoff, C., \& Maas, G. (2003). The influence of relational factors on successful succession in family businesses: A comparative study of owner-managers and successors. South African Journal of Business Management, 34(4), 1-13.

Verbeke, A., \& Kano, L. (2012). The transaction cost economics theory of the family firm: Familybased human asset specificity and the bifurcation bias. Entrepreneurship Theory and Practice, 36(6), 1183-1205.

*Vollero, A., Siano, A., \& Della Volpe, M. (2019). A systems perspective for conceptualizing sustainability in long-lived family businesses. Research proposals on risk taking and innovativeness. Systems Research and Behavioral Science, 36(1), 111-127.

*Waldkirch, M., Nordqvist, M., \& Melin, L. (2018). CEO turnover in family firms: How social exchange relationships influence whether a non-family CEO stays or leaves. Human Resource Management Review, 28(1), 56-67.

Westphal, J. D., \& Zajac, E. J. (2013). A behavioral theory of corporate governance: Explicating the mechanisms of socially situated and socially constituted agency. The Academy of Management Annals, 7(1), 607-661.

*Zahra, S. A. (2012). Organizational learning and entrepreneurship in family firms: Exploring the moderating effect of ownership and cohesion. Small Business Economics, 38(1), 51-65.

*Zattoni, A., Gnan, L., \& Huse, M. (2015). Does family involvement influence firm performance? Exploring the mediating effects of board processes and tasks. Journal of Management, 41(4), 1214-1243.

Zellweger, T. M., Chrisman, J. J., Chua, J. H., \& Steier, L. P. (2019). Social structures, social relationships, and family firms. Entrepreneurship Theory and Practice, 43(2), 207-223.

*Zona, F. (2014). Board ownership and processes in family firms. Small Business Economics, 44(1), $105-122$.

*Zona, F. (2016). CEO leadership and board decision processes in family-controlled firms: Comparing family and non-family CEOs. Small Business Economics, 47(3), 735-753. 
Table 1. Selected Opportunities for Future Research on CCSR in FFs

\begin{tabular}{|c|c|c|c|}
\hline $\begin{array}{l}\text { Ontological framework } \\
\text { dimension/ Other aspects }\end{array}$ & Research gap & $\begin{array}{l}\text { Future research } \\
\text { directions }\end{array}$ & Examples of research questions \\
\hline CONFLICT & $\begin{array}{l}\text { 1. Conflict mostly } \\
\text { examined in its } \\
\text { negative aspects } \\
\text { overlooking the } \\
\text { positive ones }\end{array}$ & $\begin{array}{l}\text { 1a. Explore the role and } \\
\text { effect of process conflict } \\
\text { 1b. Extend the study on } \\
\text { cognitive conflict outside } \\
\text { the board/TMT and } \\
\text { examine its possible } \\
\text { implications more closely } \\
\text { 1c. Examine the mutual } \\
\text { effects and interaction } \\
\text { among different forms of } \\
\text { conflict }\end{array}$ & $\begin{array}{l}\text { - How do process and cognitive conflicts influence FF decision-making? } \\
\text { - What are the effects of process and cognitive conflicts on FF behavior and outcomes? } \\
\text { - How can FFs take advantage of cognitive conflict situations? } \\
\text { - Is the presence of cognitive conflict beneficial for the business system? What are its effect at } \\
\text { different levels (family, generational, board/TMT, organization)? } \\
\text { - When and under what conditions is cognitive conflict detrimental for FFs? } \\
\text { - Is the presence of process conflict more beneficial/detrimental in FFs vs. non-FFs? If yes, why? } \\
\text { - Is the presence of cognitive conflict more beneficial/harmful in FFs or in non-FFs? If yes, why? } \\
\text { - Is there a too-much-of-a-good-thing effect associated with process and/or cognitive conflict? } \\
\text { - Can a moderate level of relationship conflict have a positive effect by favoring beneficial forms of } \\
\text { conflict (such as cognitive conflict)? Under what conditions? } \\
\text { - How do the different forms of conflict affect each other? } \\
\text { - How do different forms of conflict interact in shaping FF behavior? Does the locus (family, } \\
\text { generational, board/TMT, organization) influence how the different forms interact and their overall } \\
\text { positive or negative effect? }\end{array}$ \\
\hline COHESION & $\begin{array}{l}\text { 2. Cohesion mostly } \\
\text { examined in its } \\
\text { positive aspects } \\
\text { overlooking the } \\
\text { negative ones }\end{array}$ & $\begin{array}{l}\text { 2a. Explore the negative } \\
\text { effects of too much } \\
\text { cohesion } \\
\text { 2b. Explore the effect of } \\
\text { no cohesion and/or } \\
\text { extremely low cohesion }\end{array}$ & $\begin{array}{l}\text { - Which aspects/levels of cohesion are harmful for FFs? } \\
\text { - Is the groupthink of highly cohesive FFs detrimental/risky? In what ways and why? } \\
\text { - How can FFs avoid groupthink in the presence of cohesion? } \\
\text { - How can FFs ensure that cohesion has a positive effect within the organization? } \\
\text { - How does cohesion shape relationships and group behavior among family members? Does it shape } \\
\text { relationships and group behavior differently among non-family members? } \\
\text { - Is the presence of cohesion more beneficial/harmful in FFs versus non-FFs? If yes, why? } \\
\text { - What are the effects associated with extremely low cohesion? } \\
\text { - Is there a too-much-of-a-good-thing effect associated with cohesion? What are the optimal levels } \\
\text { and forms of cohesion? }\end{array}$ \\
\hline $\begin{array}{l}\text { CONFLICT AND } \\
\text { COHESION }\end{array}$ & $\begin{array}{l}\text { 3. Conflict and } \\
\text { cohesion rarely } \\
\text { examined in } \\
\text { combination }\end{array}$ & $\begin{array}{l}\text { 3a. Theorize and analyze } \\
\text { the reciprocal influence } \\
\text { and interaction between } \\
\text { conflict and cohesion } \\
\text { rather than considering } \\
\text { one as the opposite of the } \\
\text { other } \\
\text { 3b. Explore the } \\
\text { relationships between } \\
\text { different forms of conflict } \\
\text { and of cohesion }\end{array}$ & $\begin{array}{l}\text { - Does cohesion mitigate or exacerbate conflict in FFs? How and why? } \\
\text { - Does conflict jeopardize or enable cohesion in FFs? How and why? } \\
\text { - What are the differences when cohesion and conflict happen in the family or in the business system? } \\
\text { - How do conflict and cohesion interact in shaping FF behavior and outcomes? } \\
\text { - How does the absence of cohesion differ from the presence of conflict? What are the } \\
\text { interconnections? } \\
\text { - What are the conditions that determine the coexistence of different forms of conflict and cohesion in } \\
\text { FFs? } \\
\text { - What is the impact of different forms of cohesion on different forms of conflict? } \\
\text { - To what extent are cohesion and conflict beneficial (detrimental) for FF performance? }\end{array}$ \\
\hline
\end{tabular}




\begin{tabular}{|c|c|c|c|}
\hline & & $\begin{array}{l}\text { 3c. Explore the } \\
\text { relationship between } \\
\text { conflict and cohesion in } \\
\text { each of the loci identified }\end{array}$ & $\begin{array}{l}\text { - Is there a too-much-of-a-good-thing effect that reduces the marginal benefits of cohesion and } \\
\text { conflict, and/or triggers negative consequences for performance? } \\
\text { - To what extent does this optimum level differ between FFs and non-FFs? } \\
\text { - Is the relationship between conflict and cohesion non-linear? If yes, what forms does it take? } \\
\text { - Does relationship conflict diminish family cohesion? If yes, how and why? } \\
\text { - What are the effects of cognitive and process conflicts on board/TMTs cohesion? } \\
\text { - How do family conflicts influence cohesion in FFs? } \\
\text { - How does the perception of cohesion/conflict influence the emergence of conflict/cohesion, and vice } \\
\text { versa? } \\
\text { - How do conflict and cohesion interact in each of the loci identified (family, generations, } \\
\text { board/TMT, organization)? }\end{array}$ \\
\hline $\begin{array}{l}\text { FAMILY VS. NON-FAMILY } \\
\text { FIRM DIFFERENCES }\end{array}$ & $\begin{array}{l}\text { 4. Family and non- } \\
\text { family firms rarely } \\
\text { compared within the } \\
\text { same study }\end{array}$ & $\begin{array}{l}\text { 4b. Understand how the } \\
\text { peculiarities of FFs affect } \\
\text { the occurrence, nature } \\
\text { and level of conflict and } \\
\text { cohesion, and their } \\
\text { management }\end{array}$ & $\begin{array}{l}\text { - Does conflict and/or cohesion happen differently in FFs versus non-FFs? How and why? } \\
\text { - How and why do FFs differ from non-FFs in the capabilities needed to achieve cohesion and/or } \\
\text { mitigate conflicts? } \\
\text { - Are there differences between FFs and non-FFs in the importance attached to specific types of } \\
\text { cohesion? } \\
\text { - Is preventing conflict perceived as more important in FFs compared to non-FFs? If yes, why? } \\
\text { - How and why do the distinctive feature of the FF setting lead to differences in the nature and level } \\
\text { of conflict and/or cohesion in FFs compared to non-FFs? } \\
\text { - How and why does the overlap of the family and business systems alter the perception of conflict } \\
\text { and/or cohesion in FFs compared to non-FFs? } \\
\text { - How can family science theories be used to more comprehensively to examine the role of the family } \\
\text { system in shaping conflict and cohesion in FFs compared to non-FFs? }\end{array}$ \\
\hline $\begin{array}{l}\text { FAMILY FIRM } \\
\text { HETEROGENITY }\end{array}$ & $\begin{array}{l}\text { 5. Predominant focus } \\
\text { on how to manage } \\
\text { conflict/create } \\
\text { cohesion rather than } \\
\text { heterogeneous family } \\
\text { firm characteristics } \\
\text { that may determine } \\
\text { variations in conflict/ } \\
\text { cohesion dynamics }\end{array}$ & $\begin{array}{l}\text { 5a. Explore what aspects } \\
\text { of family firm } \\
\text { heterogeneity drive } \\
\text { differences in conflict and } \\
\text { cohesion across FFs }\end{array}$ & $\begin{array}{l}\text { - How and why do heterogeneous governance structures (in terms of both composition and } \\
\text { - How and why do heterogeneous goals among different FFs differently shape conflict and/or } \\
\text { cohesion? } \\
\text { - How and why do heterogeneous resource configurations differently shape conflict and/or cohesion? } \\
\text { - How do variations across FFs in terms of temporal factors, such as the generation of family control, } \\
\text { duration of family involvement, and intra-family succession, differently shape conflict and/or } \\
\text { cohesion? } \\
\text { - How can family science theories be used to theorize how and why conflict and cohesion differ } \\
\text { across FFs depending on different family structures, functions, interactions, and events? }\end{array}$ \\
\hline METHODS AND DATA & $\begin{array}{l}\text { 6. Prevalence of cross- } \\
\text { sectional studies }\end{array}$ & $\begin{array}{l}\text { 6a. Adopt a longitudinal } \\
\text { perspective and conduct } \\
\text { longitudinal studies on } \\
\text { conflict and cohesion }\end{array}$ & $\begin{array}{l}\text { - How do FF conflicts and cohesion change over time? } \\
\text { - What are the implications of repeated conflicts and/or cohesion over time? } \\
\text { - What is the process by which conflict and/or cohesion manifest in FFs? } \\
\text { - How do conflict/cohesion episodes at a specific point in time affect conflict/cohesion episodes at a } \\
\text { future point in time? } \\
\text { - How can scholars effectively develop longitudinal studies tracing over time conflict and cohesion } \\
\text { dynamics in FFs? Are there available datasets? }\end{array}$ \\
\hline
\end{tabular}


7a. Conduct qualitative studies that investigate more in-depth conflict, cohesion and thei interconnections

7. Prevalence of quantitative studies

8. Focus on selected geographical areas

Europe and North

America)

8a. Conduct studies in

Latin America, Easter

Europe and Africa
- How can qualitative approaches (case studies, ethnographic approaches, process studies, discourse studies) be applied to understand the multi-level complexity of conflict and cohesion dynamics over time within the real-life context where they occur?

- How can experimental methods and simulations be applied to understand the micro-foundations of conflict and/or cohesion formation, management and dissolution, and isolate the causal mechanisms involved?

- How can qualitative comparative analysis (QCA) approaches be used to understand how

heterogeneous FF configurations, and related changes, result in similar conflict and/or cohesion outcomes?

- How can scholars leverage the richness of qualitative research approaches to study conflict and cohesion in FFs?

- Do differences in the national culture affect conflict and/or cohesion? How?

- How do differences across institutional contexts regarding the role of different family actors (e.g., female vs. male, new vs. old) involved in conflict and/or cohesion dynamics affect conflict and/or cohesion?

- How do different family values, family structures, and family functions across different institutional contexts affect conflict and/or cohesion? 
STEP 1. Search on ISI Web of Science ${ }^{\circledR}$, EBSCO Business Source Premier (BSP), and Econlit using the following keywords related to conflict and cohesion in FFs:

("family business*” OR "family firm*” OR "family enter*” OR "familin*” OR "family control*” OR "family led*” OR "family owner*" OR "family-based") AND ("Social Capital*" OR "tie*” OR "cohesi*” OR "harmon*” OR "attachment*"

OR "love" OR "affection" OR “conflict*” OR “disagree*” OR “disharmon*” OR “dislik*” OR "strif*” OR “tension”)

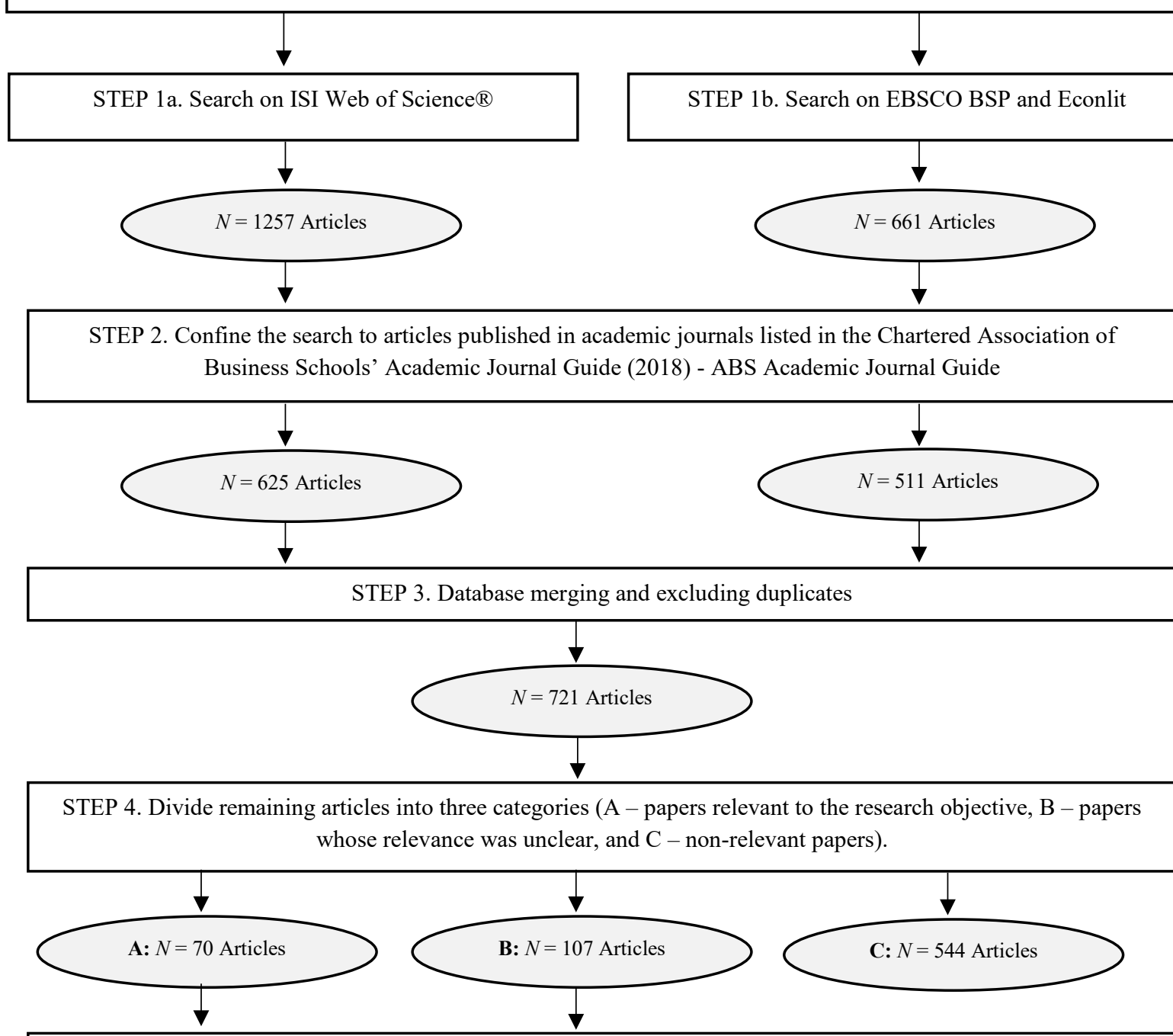

STEP 5. Read and discuss the B papers for inclusion of only relevant articles in line with the literature review scope

STEP 6. Look at the studies in the sample papers' reference list (backward citation) and check their relevance through independent readings of manuscripts by each of the co-authors

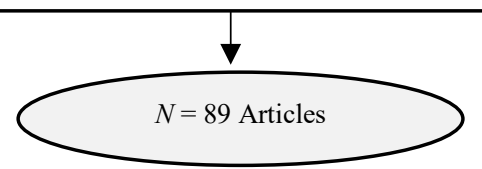

Figure 1. Search Procedure for Selecting Articles on CCSR in FFs 


\section{Drivers}

Altruism (-) Eddleston \& Kellermanns (2007); Morgan \& Gómez-Mejía (2014)*

- Presence of non-family managers $(+)$ Sonfield \& Lussier (2009)

- Trust (-) Kudlats et al. (2019)

- Women on boards (-) Samara et al. (2019)*

\section{Outcomes}

(2007) - Knowledge internalization (-) Chirico \& Salvato (2016) - Product development (-) Chirico \& Salvato (2016)

- Subjective firm valuations (+/-) Rousseau et al. (2018)

- Negative emotions among family members (+) Morgan \& Gómez-Mejía (2014)*

- Family member impediment (+) Kidwell et al. (2012)

- Human and financial capital (-) Scholes et al. (2016)

- Family business growth (-) Lambrecht \& Lievens (2008)
Drivers

scession process (-) Filser et al. (2013)*, Brenes et al.

(2006)

- Family focus on shared stories (-) Kammerlander et al. (2015)

- Rivalry/conflict management (-) Pardo-del-Val (2009)

- Strategies to transmit responsible family ownership (-) AragonAmonarriz et al. (2019)

- Third or later generations leading the firm (+) Davis \&

Harverston (1999)

- Founder's generational shadow (+) Davis \& Harverston (1999) - Projective identification (+) Petriglieri \& Stein (2012)

- Influential family members at work (+) Davis \& Harverston (2001)

- Influential family members not at work (+/-) Davis \&

Harverston (2001)

- Social interaction among family members (+) Davis \&

Harverston (2001)

- Successor team formation (+/-) Cater et al. (2016)

- The nuber of generations (+) de Vies (1993)*

- Family unity (-) Jaskiewicz et al. (2016)

- Cohesive family culture (-) Jaskiewicz et al. (2016)

Colitarian lo

- Offspring feeling of exclusion (+) Haberman \& Danes (2007)

- Deficient communication (+) Michael-Tsabari \& Weiss

(2015)*

\section{Outcomes}

mily firm transition (-) Morris et al. (1997)

- Firm innovation (-) Kammerlander et al. (2015)

- Firm continuity and longevity (-) Kiong (2005); Cater et al

(2016)

Formation of new businesses (+) Cater et al. (2016)

Family harmony (-) Jayantilal et al. (2016)*

Successful business transition (-) Nazar \& Llorca-Jaña (2020)

Breakup of a group of business assets (+) Fernandéz-Roca et al. (2014)

Generational Conflic

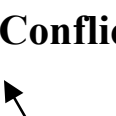

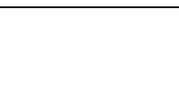

\section{Drivers}

Dith equal ownership dispersion (+) Zona (2014)

- Family involvement (-) Zattoni et al. (2015)

- Short and long-term pay dispersion (+/-) Ensley et al. (2007)

- TMT composed only of parental family members (-) Ensley

\& Pearson (2005)

\section{Outcomes}

- Board service task performance (+) Zona (2016)

- Board strategy tasks performance (+) Zattoni et al. (2015)

- Firm performance (+/-) Zattoni et al. (2015); Ensley et al.

(2007)

monitoring activities (+) Goergen et al. (2015)

Cognitive conflict proxied by age difference

Firm value (for firms in need of monitoring) (+) Goergen et

al. (2015) Cognitive conflict proxied by age difference

\section{Drivers}

f fair process (-) Van der Heyden et al. (2005) Participative decision-making (+/-) Eddleston et al. (2008) - Concentration of control (+/-) Kellermanns \& Eddleston $(2004)^{*}$

\section{Outcomes}

(2007); Kellermanns \& Eddleston (2004)*

- Effective decision-making (+) Kellermanns \& Eddleston (2004)*

Family Conflict
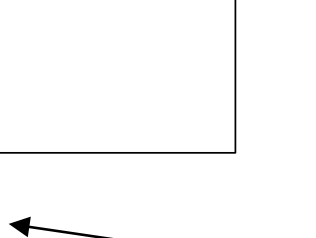

L

\section{Board/TMT Conflict}

Organizational Conflict 


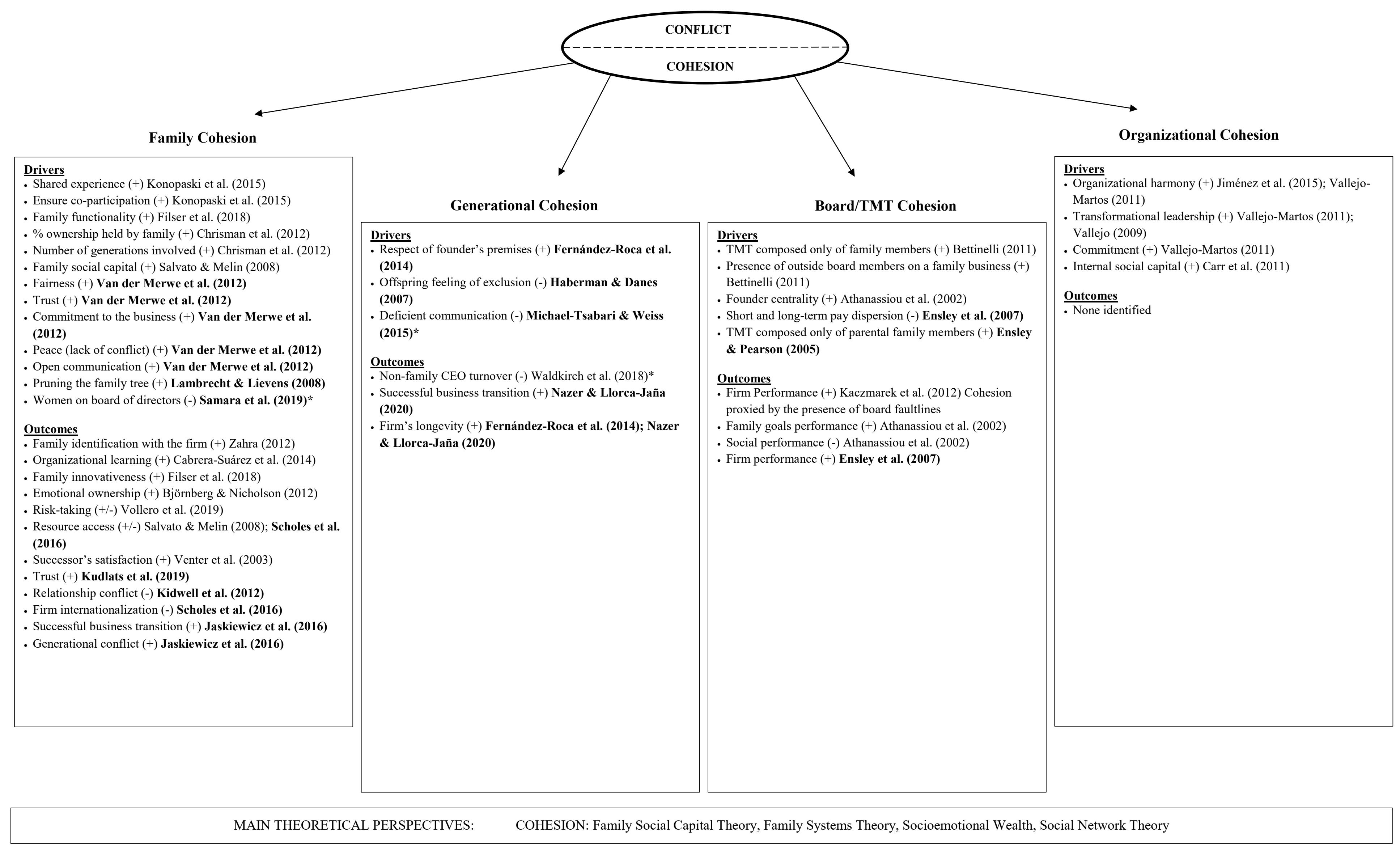

Figure 2b. Ontological Framework for Organizing the Literature on CCSR in FFs

(Notes: $+/$ - in brackets indicate the sign of the relationship between the item and conflict or cohesion; in bold the studies that jointly study conflict and cohesion; * $=$ non-empirical studies) 
Table A1. Examination of Conflict in Prior Research: Drivers, Outcomes, and Theories adopted (in bold studies that jointly study conflict and cohesion; *= non-empirical studies)

\begin{tabular}{|c|c|c|c|c|c|}
\hline Locus & Driver & Main Theory & Outcome & Main Theory & $\begin{array}{l}\text { No explicit examination of drivers and } \\
\text { outcomes }\end{array}$ \\
\hline FAMILY CONFLICT & $\begin{array}{l}\text { - Altruism (-) } \\
\text { Eddleston \& Kellermanns (2007); } \\
\text { Morgan \& Gómez-Mejia (2014)** } \\
\text { - Presence of non-family managers (+) } \\
\text { Sonfield \& Lussier (2009) } \\
\text { - Women on board of directors (-) } \\
\text { Samara et al. (2019)* } \\
\text { - Trust (-) Kudlats et al. (2019) }\end{array}$ & $\begin{array}{l}\text { Stewardship theory; } \\
\text { socioemotional wealth perspective/ } \\
\text { social exchange theory } \\
\text { n.e. (relies on family business and } \\
\text { conflict literatures) } \\
\text { n.e. (use of family business and } \\
\text { corporate governance literature) } \\
\text { Intergroup theory }\end{array}$ & $\begin{array}{l}\text { - Human and financial capital (-) } \\
\text { Scholes et al. (2016) } \\
\text { - Firm performance } \\
\text { (-) } \\
\text { Eddleston \& Kellermanns (2007) } \\
\text { - Subjective firm valuations (+/-) } \\
\text { Rousseau et al. (2018) } \\
\text { - Knowledge internalization (-); } \\
\text { Product development } \\
\text { (-) } \\
\text { Chirico \& Salvato (2016) } \\
\text { - Family business growth (-) } \\
\text { Lambrecht \& Lievens (2008) } \\
\text { - Family member impediment (+) } \\
\text { Kidwell et al. (2012) } \\
\text { - Negative emotions among family } \\
\text { members (+) } \\
\text { Morgan \& Gómez-Mejía (2014)* }\end{array}$ & $\begin{array}{l}\text { Socioemotional wealth perspective, } \\
\text { behavioral agency model, mixed } \\
\text { gambles, which are all three grounded } \\
\text { in prospect theory } \\
\text { Knowledge-based theoretical approach } \\
\\
\text { Procedural Justice Theory (social } \\
\text { scientists-psychology) } \\
\text { Leader member exchange and group } \\
\text { value model of justice (use of ethical } \\
\text { climate literature and family business } \\
\text { literature) } \\
\text { Socioemotional wealth perspective/ } \\
\text { social exchange theory }\end{array}$ & $\begin{array}{l}\text { - Van der Merwe et al. (2012) } \\
\text { - Chirico et al. (2011) } \\
\text { - Duréndez et al. (2019) } \\
\text { - Le Breton-Miller \& Miller (2014) } \\
\text { - Gagné et al. (2014)* } \\
\text { - Herrero (2018) } \\
\text { - Pearson et al. (2014) } \\
\text { - Schmidts (2013) } \\
\text { - Sharma \& Sharma (2011)* } \\
\text { - Beehr et al. (1997) }\end{array}$ \\
\hline \multirow[t]{3}{*}{$\begin{array}{l}\text { GENERATIONAL } \\
\text { CONFLICT }\end{array}$} & $\begin{array}{l}\text { - Family unity (-); Cohesive family culture (-); Egalitarian leadership style (-) } \\
\text { Jaskiewicz et al. (2016) } \\
\text { - Plan the succession process (-) Filser, et al. (2013)*; Brenes et al. (2006) }\end{array}$ & $\begin{array}{l}\text { Institutional Theory } \\
\text { n.a.; } \\
\text { n.e. (use of family business literature) }\end{array}$ & $\begin{array}{l}\text { - Successful business transition (-) } \\
\text { Nazer \& Llorca-Jaña (2020) } \\
\text { - Firm continuity and longevity (-) } \\
\text { Kiong (2005); Cater et al. (2016) } \\
\text { Formation of new businesses (+) } \\
\text { Cater et al. (2016) }\end{array}$ & $\begin{array}{l}\text { n.e. (use of family business succession } \\
\text { literature) } \\
\text { n.e. (reference to literature on sociology } \\
\text { and family firms); conflict theory + } \\
\text { diffferent literatures: family and team } \\
\text { dynamics in succession }\end{array}$ & $\begin{array}{l}\text { - De Clercq \& Belausteguigoitia (2015)* } \\
\text { - Bobillo et al. (2013) } \\
\text { - Nicholson (2008)* } \\
\text { - Marshall et al. (2006) } \\
\text { - Discua Cruz et al. (2013) } \\
\text { - Avloniti iet al. (2014)* } \\
\text { - Levinson (1991)* } \\
\text { - Sreih et al. (2019) }\end{array}$ \\
\hline & $\begin{array}{l}\text { - Offspring feeling of exclusion (+) Haberman \& Danes (2007) } \\
\text { - Family focus in shared stories (-) Kammerlander et al. (2015) }\end{array}$ & $\begin{array}{l}\text { The family FIRO (fundamental } \\
\text { interpersonal } \\
\text { relationship orientation) model } \\
\text { Organizational (and innovation) theory }\end{array}$ & $\begin{array}{l}\text { - Firm innovation (-) Kammerlander } \\
\text { et al. (2015) } \\
\text { - Breakup of a group of business } \\
\text { assets (+) Fernández-Roca et al. } \\
\text { (2014) }\end{array}$ & $\begin{array}{l}\text { Organizational (and innovation) theory } \\
\text { n.e. (use of business history and family } \\
\text { business literature) }\end{array}$ & \\
\hline & $\begin{array}{l}\text { - Third or later generations leading the family firm (+); Founder’s generational } \\
\text { shadow (+) Davis \& Harveston (1999) } \\
\text { - Influential family members at work (+); Influential family members not at work } \\
\text { (+/-); Social interaction among family members (+) Davis \& Harveston (2001) } \\
\text { - Deficient communication (+) Michael-Tsabari \& Weiss (2015)* } \\
\text { - Projective identification (+) Petriglieri \& Stein (2012) } \\
\text { - Generation's number (+)* de Vries (1993) } \\
\text { - Strategies to transmit responsible family ownership (-) Aragón-Amonarriz et al. } \\
(2019) \\
\text { - Rivalry/conflict management (-) Pardo-del-Val (2009) } \\
\text { - Successor team formation (+/-) Cater et al. (2016) }\end{array}$ & $\begin{array}{l}\text { n.e. (use of family business succession } \\
\text { literature) } \\
\text { Conflict theory } \\
\text { Game theory } \\
\text { Systems psychodynamic perspective } \\
\text { n.e. (use of psychology literature) } \\
\text { n.e. (reference to stewardship theory, } \\
\text { socioemotional wealth and literatures } \\
\text { on family social capital-family business } \\
\text { Change management theory (mainly } \\
\text { from an organizational behavior } \\
\text { perspective) } \\
\text { Conflict theory + different literatures: } \\
\text { family and team dynamics in succession }\end{array}$ & $\begin{array}{l}\text { - Smooth family firm transition (-) } \\
\text { Morris et al. (1997) } \\
\text { - Family harmony (-) } \\
\text { Jayantilal et al. (2016)* }\end{array}$ & $\begin{array}{l}\text { n.e. (use of family business succession } \\
\text { literature) } \\
\text { Game theory }\end{array}$ & \\
\hline $\begin{array}{l}\text { BOARD/TMT } \\
\text { CONFLICT }\end{array}$ & - TMT composed only by parental family members (-) Ensley \& Pearson (2005) & $\begin{array}{l}\text { Upper echelon/ theories on behavioral } \\
\text { dynamics of teams }\end{array}$ & $\begin{array}{l}\text { - Firm performance (+/-) Zattoni et } \\
\text { al. (2015); Ensley et al. (2007); }\end{array}$ & $\begin{array}{l}\text { Process-based view of boards of } \\
\text { directors }+ \text { agency/resource dependence }\end{array}$ & $\begin{array}{l}\text { - Sciascia et al. (2013) } \\
\text {. Schjoedt et al. (2013)* }\end{array}$ \\
\hline
\end{tabular}




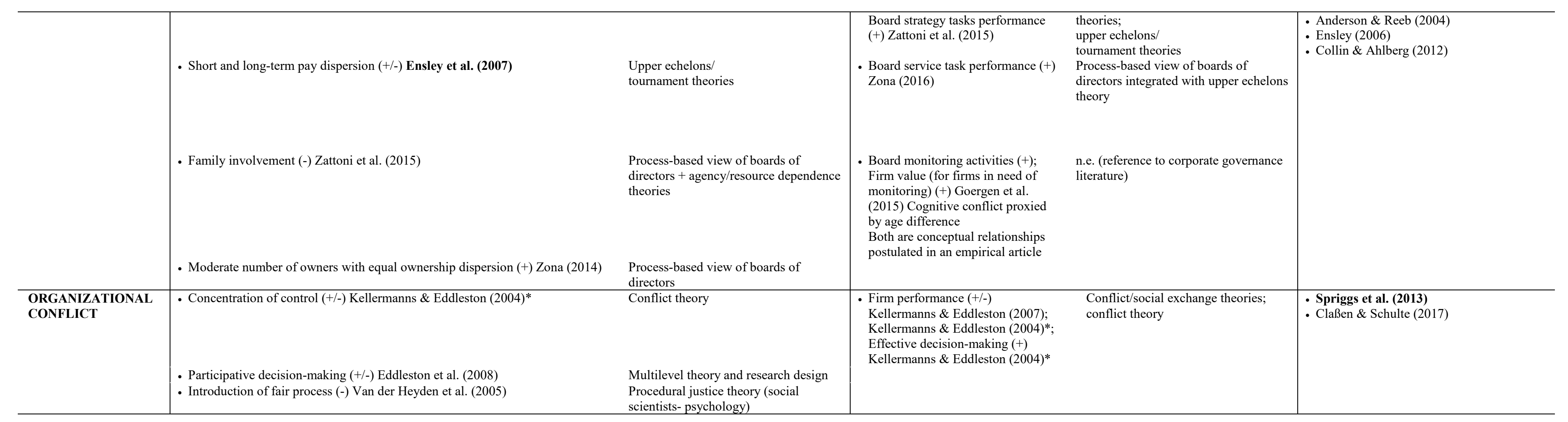

Table A2. Examination of Cohesion in Prior Research: Drivers, Outcomes and Theories adopted (in bold studies that jointly study conflict and cohesion; * = non-empirical studies)

\begin{tabular}{|c|c|c|c|c|c|}
\hline Locus & Driver & Main Theory & Outcome & Main Theory & $\begin{array}{l}\text { No explicit examination of drivers and } \\
\text { outcomes }\end{array}$ \\
\hline $\begin{array}{l}\text { FAMILY } \\
\text { COHESION }\end{array}$ & $\begin{array}{l}\text { - Fairness (+); trust (+) } \\
\text { commitment to the business (+); peace (lack of conflict) (+) } \\
\text { open communication (+) Van der Merwe et al. (2012) } \\
\text { - Family social capital (+) Salvato \& Melin (2008) } \\
\text { - Shared experience (+); Ensure co-participation (+) Konopaski et al. (2015) } \\
\text { - Pruning the family tree (+) Lambrecht \& Lievens (2008) } \\
\text { - \% ownership held by family (+); Number of generations involved (+) Chrisman } \\
\text { et al. (2012) } \\
\text { - Women in board of directors (-) Samara et al. (2019)* } \\
\text { - Family functionality (+) Filser et al. (2018) }\end{array}$ & $\begin{array}{l}\text { Social capital theory (sociology) } \\
\text { Situated learning perspective } \\
\text { Procedural justice theory (social } \\
\text { scientists-psychology) } \\
\text { Behavioral/stakeholder theories } \\
\text { (organizational studies) } \\
\text { n.e. (use of family business and } \\
\text { corporate governance literature) } \\
\text { Socioemotional wealth perspective/ } \\
\text { family functionality view (from } \\
\text { sociology) }\end{array}$ & $\begin{array}{l}\text { - Family identification with the firm } \\
\text { (+) Cabrera-Suárez et al. (2014) } \\
\text { - Successulul business transition (+); } \\
\text { Generational conflict (-) } \\
\text { Jaskiewizic et al. (2016) } \\
\text { - Relationship conflict (-); family } \\
\text { member impediment (-) Kidwell et } \\
\text { al. (2012) indirect } \\
\text { - Firm internationalization } \\
\text { (-) Scholes et al. (2016) } \\
\text { - Resource access (+/-) Scholes et al. } \\
\text { (2016); } \\
\text { Salvato \& Melin (2008) } \\
\text { - Trust (+) Kudlats et al. (2019) } \\
\text { - Emotional ownership (+) Björnberg } \\
\text { \& Nicholson (2012) } \\
\text { - Successor's satisfaction (+) Venter } \\
\text { et al. (2003) } \\
\text { - Family innovativeness (+) Filser et } \\
\text { al. (2018) }\end{array}$ & $\begin{array}{l}\text { Socioemotional wealth perspective } \\
\text { Institutional theory } \\
\text { Leader member exchange and group } \\
\text { value model of justice (use o fethical } \\
\text { climate literature and family business } \\
\text { literature) } \\
\text { Socioemotional wealth perspective; } \\
\text { social capital theory (sociology) } \\
\text { Intergroup theory } \\
\text { Attachment/ } \\
\text { social identity theory (from social } \\
\text { psychology) } \\
\text { n.e. (use of family business literature) } \\
\text { Socioemotional wealth perspective/ } \\
\text { family functionality view (from } \\
\text { sociology) }\end{array}$ & $\begin{array}{l}\text { - Eddleston \& Morgan (2014)* } \\
\text { - Herrero \& Hughes (2019) } \\
\text { - Sanchez-Ruiz et al. (2019) } \\
\text { - Herrero (2018) } \\
\text { - Pearson et al. (2014) } \\
\text { - Qin \& Deng (2016) } \\
\text { - Michael-Tsabari \& Tan (2013) } \\
\text { - Long \& Mathews (2011)* } \\
\text { - Sharma \& Sharma (2011)* } \\
\text { - Björnberg \& Nicholson (2007) } \\
\text { - Lee (2006) } \\
\text { - Beehr et al. (1997) }\end{array}$ \\
\hline
\end{tabular}




\begin{tabular}{|c|c|c|c|c|c|}
\hline & & & $\begin{array}{l}- \text { Risk-taking }(+/-) \text { Vollero et al. } \\
(2019)\end{array}$ & Systems theory & \\
\hline \multirow[t]{2}{*}{$\begin{array}{l}\text { GENERATIONAL } \\
\text { COHESION }\end{array}$} & $\begin{array}{l}\text { - Offspring feeling of exclusion (-) Haberman \& Danes (2007) } \\
\text { - Respect of founder's premises (+) } \\
\text { Fernández-Roca et al. (2014) }\end{array}$ & $\begin{array}{l}\text { The family FIRO (fundamental } \\
\text { interpersonal } \\
\text { relationship orientation) model } \\
\text { n.e. (use of business history and family } \\
\text { business literatures) }\end{array}$ & $\begin{array}{l}\text { - Non-family CEO turnover (-) } \\
\text { Waldkirch et al. (2018)* } \\
\text { - Firm's longevity }(+) \\
\text { Fernández-Roca et al. (2014); } \\
\text { Nazer \& Llorca-Jaña (2020) } \\
\text { - Successful business transition (+) } \\
\text { Nazer \& Llorca-Jaña (2020) }\end{array}$ & $\begin{array}{l}\text { Social exchange perspective } \\
\\
\text { n.e. (use of business history and family } \\
\text { business literatures); } \\
\text { n.e. (use of family business succession } \\
\text { literature) }\end{array}$ & - De Clercq \& Belausteguigoitia (2015)" \\
\hline & - Deficient communication (-) Michael-Tsabari \& Weiss (2015)* & Game theory & & & \\
\hline \multirow[t]{3}{*}{$\begin{array}{l}\text { BOARD/TMT } \\
\text { COHESION }\end{array}$} & $\begin{array}{l}\text { - Short and long-term pay dispersion (-) Ensley et al. (2007) } \\
\text { - Founder centrality (+) Athanassiou et al. (2002) }\end{array}$ & $\begin{array}{l}\text { Upper echelons/ } \\
\text { tournament theories } \\
\text { Social network theory }\end{array}$ & $\begin{array}{l}\text { - Firm performance (+) Ensley et al. } \\
\text { (2007) } \\
\text { - Family goals performance }(+) \text {; } \\
\text { Social performance } \\
\text { (-) Athanassiou et al. (2002) }\end{array}$ & $\begin{array}{l}\text { Upper echelons/ } \\
\text { tournament theories } \\
\text { Social network theory }\end{array}$ & - Sciascia et al. (2013) \\
\hline & $\begin{array}{l}\text { - TMT composed only by family members }(+) \text {, Presence of outside board } \\
\text { members on a family business }(+) \text { Bettinelli }(2011)\end{array}$ & $\begin{array}{l}\text { Process-based view of boards with } \\
\text { agency theory; stewardship theory, } \\
\text { resource dependence theory integrated }\end{array}$ & $\begin{array}{l}\text { - Firm Performance (+) } \\
\text { Kaczmarek et al. (2012) cohesion } \\
\text { proxied by the presence of board } \\
\text { faultlines }\end{array}$ & Social identity theory (main theory) & \\
\hline & - TMT composed only by parental family members (+) Ensley \& Pearson (2005) & $\begin{array}{l}\text { Upper echelon/ theories on behavioral } \\
\text { dynamics of teams }\end{array}$ & & & \\
\hline $\begin{array}{l}\text { ORGANIZATIONAL } \\
\text { COHESION }\end{array}$ & $\begin{array}{l}\text { - Transformational leadership (+) Vallejo-Martos (2011); } \\
\text { Vallejo (2009) } \\
\text { - Commitment (+) Vallejo-Martos (2011) } \\
\text { - Organizational harmony (+) Vallejo-Martos (2011); } \\
\text { Jiménez et al. (2015) } \\
\text { - Internal social capital (+) Carr et al. (2011) }\end{array}$ & $\begin{array}{l}\text { Neo-institutional/ } \\
\text { transformational leadership theories; } \\
\text { institutional/ } \\
\text { transformational leadership theory } \\
\text { Neo-institutional// } \\
\text { transformational leadership theories; } \\
\text { institutional theory and family social } \\
\text { capital theory } \\
\text { Social capital theory (sociology) }\end{array}$ & None identified & & $\begin{array}{l}\text { - Spriggs et al. (2013) } \\
\text { - Miller et al. (2009) }\end{array}$ \\
\hline
\end{tabular}

